\title{
Reassessing Marine Fishery Intensification in Southeast Queensland
}

\author{
Sean Ulm \\ Aboriginal and Torres Strait Islander Studies Unit, University of Queensland, Brisbane, Queensland, 4072, Australia
}

\begin{abstract}
A review of the archaeological evidence underlying a model by Walters of late Holocene Aboriginal marine fishery intensification in southeast Queensland is undertaken. The results of a regional review of the available fish bone neither support an argument for a general pattern of increase in fish discard at coastal sites nor the claim for an exponential increase through time in the number of sites exhibiting fish remains. Major taphonomic issues and research biases are considered to have played a role in structuring the archaeological database of the region.
\end{abstract}

\section{Introduction}

Since the mid-1980s, Walters (1986, 1988, 1989, 1992a, 1992b, 1992c, 2001) has developed and defended a model of late Holocene fishery intensification for Moreton Bay and southeast Queensland generally. His model represents one of several recent syntheses of late Holocene culture change in southeast Queensland which feature marine resources (especially fish) (e.g. Hall 1982, 1987, 1990, 1999, 2000; Hall and Hiscock 1988; McNiven 1990a, 1991a, 1992a, 1999; Morwood 1986, 1987). As one of a few available wide-ranging regional explanatory models, Walters' view of late Holocene change has become an important referential framework for other studies. Sporadic debate centred on his model has variously focussed on the antiquity of marine fishing (Frankland 1990; Walters 1992c), taphonomic issues (McNiven 1991a), recovery methods (Ross and Coghill 2000; Ross and Duffy 2000) and the concept of intensification itself (Arnold 1993:8485). Paradoxically, despite energetic debates about the role and relative importance of marine fish in the late Holocene archaeological record of southeast Queensland, no systematic review and evaluation of the basic archaeological evidence for fishing has been undertaken. This paper represents such an evaluation of the region's archaeological record as a means of assessing the indices of intensified marine fishing employed by Walters. Archaeological fish remains from 23 sites are systematically reviewed prior to a synthesis of the evidence for marine fishing and a discussion of the main taphonomic issues and research biases that have played a role in structuring the region's archaeological database.

\section{Walters' Model}

Walters (1986, 1988, 1989, 1992a, 1992b, 1992c, 2001) developed an explanatory model linking increased discard of marine fish remains in the late Holocene to intensifying regional social networks. He attributed a time-lag of some 4,000 years between mid-Holocene sea level stabilisation and human occupation of the coast to the marginality of the coastal landscape prior to late Holocene increases in marine productivity induced by anthropogenic changes in fluvial sedimentation. In the absence of significant terrestrial resources, the development of specialised production systems predicated on marine fish is argued to have been necessary for permanent occupation of the coastal lowlands. Furthermore, the adoption of specialised marine fishing was viewed by Walters as requiring a transition from mobile hunting and gathering of terrestrial resources to more sedentary marine resource-based production involving radical restructuring of existing social structures and ideological systems, accompanied by significant population growth.

Walters derived archaeological evidence for the development of the fishery from eight coastal shell middens in a variety of ecological settings around Moreton Bay: Sandstone Point; St Helena Island; Toulkerrie; Wallen Wallen Creek; Minner Dint; NRS 7; NRS 8; and NRS 10 (Figure 1). On the basis of these analyses, Walters (1989:220; also 1986:318-320, 1992a) identified three main indicators of intensifying marine fishing activities: (i) the establishment of new fishing territories by eastward expansion of people to the islands of Moreton Bay; (ii) an exponential increase through time in the number of sites containing marine fish remains; and, (iii) increased intensity of fish remain discard through time. The last two of these indicators are examined in this paper.

\section{The Archaeological Evidence for Fishing}

Over the past 40 years, archaeological investigations in southeast Queensland have focussed almost exclusively on the coastal strip (but see, for example, Smith and Hall 1996). Although little of the region has been systematically surveyed, over 1,500 coastal midden sites have been documented (Aiken et al. 1992), 62 of which have been excavated (Table 1). Of these 62 sites, 27 are said to contain fish remains, although only 23 have been reported with even basic details and only 21 have been radiometrically dated (Table 1 ). In order to assess the archaeological evidence for chronological change in marine fish production, each of these 21 sites, plus the undated NRS 7 and NRS 10 sites which are used by Walters to derive his model, are systematically reviewed.

At the outset it was intended to synthesise the archaeological evidence for marine fishing by integrating results from analyses of fish bone assemblages into a single database. On reviewing the evidence, however, it became clear that the lack of comparability between excavations and analyses precluded any meaningful quantitative treatment of the data and presented problems for building a regional understanding of the use of fish resources. Consequently, a qualitative site-by-site review of evidence for fishing was considered more appropriate. The following sections briefly describe investigations at each dated site containing fish (plus NRS 7 and NRS 10), focussing on recovery strategies, the abundance and chronology of fish remains and potential interpretation problems. 
Table 1. Summary of shell midden excavations conducted on the southeast Queensland coast.

\begin{tabular}{|c|c|c|c|c|c|c|c|c|}
\hline Site & Year & Excavator/s & $\begin{array}{c}\text { Site } \\
\text { Area } \\
\left(\mathbf{m}^{2}\right)\end{array}$ & $\begin{array}{c}\text { Area } \\
\text { Excavated } \\
\left(\mathbf{m}^{2}\right)\end{array}$ & $\begin{array}{c}\text { Sieve } \\
\text { Size } \\
(\mathrm{mm})\end{array}$ & $\begin{array}{c}\text { Site } \\
\text { Reported }\end{array}$ & $\begin{array}{c}\text { Fish } \\
\text { Remains } \\
\text { Present }\end{array}$ & $\begin{array}{c}{ }^{14} \mathrm{C} \\
\text { Dated }\end{array}$ \\
\hline Aranarawai Beach Ridge II & - & R. Neal & - & - & - & $\mathrm{N}$ & - & $\mathrm{Y}$ \\
\hline Aranarawai Creek & - & R. Neal & - & - & - & $\mathrm{N}$ & - & $\mathrm{N}$ \\
\hline Bell's Creek & 1972 & L. Haglund & 1000 & 0.75 & - & $\mathrm{Y}$ & - & $\mathrm{N}$ \\
\hline Booral Homestead Midden & 1989 & I. McNiven & - & 0.25 & $5 / 2$ & $\mathrm{~N}$ & - & Y \\
\hline Booral Shell Mound & 1989 & I. McNiven & 120 & 0.5 & $5 / 2$ & Y & Y & Y \\
\hline Bribie Island 9 & 1992 & J. Hall & 500000 & 0.75 & $6 / 3$ & $\mathrm{Y}$ & $\mathrm{Y}$ & $\mathrm{Y}$ \\
\hline Bribie Island 67 & 1993 & J. Hall & 300000 & 1 & $6 / 3$ & $\mathrm{~N}$ & $\mathrm{Y}$ & $\mathrm{N}$ \\
\hline Broadbeach Burial Ground & $1965-8$ & L. Haglund & 285 & 228 & - & Y & Y & $\mathrm{Y}$ \\
\hline Brown's Road & $1980-1$ & M. Strong & 5000 & 8.25 & $6 / 3$ & $\mathrm{~N}$ & $\mathrm{~N}$ & $\mathrm{Y}$ \\
\hline Bundall & 1968 & L. Haglund & 2500 & 75 & - & $\mathrm{Y}$ & $\mathrm{N}$ & $\mathrm{N}$ \\
\hline Caloundra I & 1965 & D. Tugby & 5000 & 1.9 & - & Y & $\mathrm{N}$ & $\mathrm{N}$ \\
\hline Cameron Creek Site 134 & 1988 & I. McNiven & 312 & 16 & 3 & $\mathrm{Y}$ & $\mathrm{N}$ & $\mathrm{N}$ \\
\hline Cameron Point Site 62 & 1988 & I. McNiven & - & 0.75 & 3 & Y & $\mathrm{Y}$ & $\mathrm{Y}$ \\
\hline Canalpin Creek & - & R. Neal & - & - & - & - & - & $\mathrm{N}$ \\
\hline Cascade Gardens & 1970 & L. Haglund & 700 & 50 & - & Y & Y & $\mathrm{N}$ \\
\hline Cooloola Sand Patch 102 & 1988 & I. McNiven & 3000 & 10 & 3 & Y & $\mathrm{N}$ & $\mathrm{N}$ \\
\hline Double Island Point Site 1 & 1988 & I. McNiven & 20000 & 11.5 & 3 & $\mathrm{Y}$ & Y & $\mathrm{Y}$ \\
\hline First Ridge 19A & 1980 & R. Robins & 4 & 0.75 & $6 / 3$ & Y & $\mathrm{N}$ & $\mathrm{N}$ \\
\hline First Ridge 19B & 1980 & R. Robins & 4 & 0.25 & $6 / 3$ & Y & $\mathrm{Y}$ & Y \\
\hline Freshwater Creek Site & 1988 & I. McNiven & 64 & 1.75 & 3 & Y & $\mathrm{N}$ & $\mathrm{N}$ \\
\hline Hope Island & 1986 & I. Walters & - & 1.25 & 3 & $\mathrm{Y}$ & $\mathrm{N}$ & $\mathrm{Y}$ \\
\hline Kabali Site & 1988 & I. McNiven & - & 1.75 & 3 & $\mathrm{Y}$ & $\mathrm{N}$ & $\mathrm{Y}$ \\
\hline King's Bore Sandblow 97 & 1988 & I. McNiven & 10000 & 121 & 3 & $\mathrm{Y}$ & $\mathrm{Y}$ & $\mathrm{Y}$ \\
\hline Lake Coombabah & 1999 & G. Alfredson & - & - & - & Y & $\mathrm{N}$ & Y \\
\hline Lazaret Midden & $\begin{array}{l}1995 \\
1998 \\
\end{array}$ & $\begin{array}{l}\text { A. Ross } \\
\text { Quandamooka }\end{array}$ & $\begin{array}{l}- \\
-\end{array}$ & 1 & $\begin{array}{l}6 / 3 / 1 \\
6 / 3 / 1\end{array}$ & $\begin{array}{l}\mathrm{Y} \\
\mathrm{Y}\end{array}$ & $\begin{array}{l}\mathrm{Y} \\
\mathrm{Y}\end{array}$ & $\begin{array}{l}\mathrm{Y} \\
\mathrm{Y}\end{array}$ \\
\hline Leisha Track Site 93 & 1988 & I. McNiven & 150 & 21 & 3 & $\mathrm{Y}$ & $\mathrm{N}$ & $\mathrm{N}$ \\
\hline Little Sandhills & 1980 & R. Robins & 90 & 90 & $6 / 3$ & $\mathrm{Y}$ & $\mathrm{Y}$ & $\mathrm{Y}$ \\
\hline Madonna & - & R. Neal & - & - & - & $\mathrm{N}$ & - & $\mathrm{N}$ \\
\hline Maroochy River 2 & 1988 & I. McNiven & 2000 & 0.25 & 3 & Y & $\mathrm{N}$ & Y \\
\hline Maroochy River 4 & 1988 & I. McNiven & 4400 & 1 & 3 & $\mathrm{Y}$ & $\mathrm{N}$ & $\mathrm{Y}$ \\
\hline Minner Dint & 1978 & J. Hall & - & 4 & 3 & $\mathrm{Y}$ & $\mathrm{Y}$ & $\mathrm{Y}$ \\
\hline New Brisbane Airport & $\begin{array}{l}1984 \\
1987 \\
1988 \\
1989 \\
\end{array}$ & $\begin{array}{l}\text { J. Hall } \\
\text { J. Hall } \\
\text { J. Hall } \\
\text { J. Hall }\end{array}$ & $\begin{array}{l}- \\
- \\
- \\
-\end{array}$ & $\begin{array}{r}0.25 \\
-\quad 1 \\
-\quad \\
-\end{array}$ & $\begin{array}{l}6 / 3 \\
6 / 3 \\
6 / 3 \\
6 / 3 \\
\end{array}$ & $\begin{array}{l}\mathrm{Y} \\
\mathrm{Y} \\
\mathrm{N} \\
\mathrm{N}\end{array}$ & $\begin{array}{l}\mathrm{N} \\
\mathrm{Y} \\
\mathrm{Y} \\
\mathrm{Y}\end{array}$ & $\begin{array}{l}\mathrm{Y} \\
\mathrm{Y} \\
\mathrm{Y} \\
-\end{array}$ \\
\hline
\end{tabular}


Table 1. Summary of shell midden excavations conducted on the southeast Queensland coast (cont.).

\begin{tabular}{|c|c|c|c|c|c|c|c|c|}
\hline Site & Year & Excavator/s & $\begin{array}{c}\text { Site } \\
\text { Area } \\
\left(\mathbf{m}^{2}\right)\end{array}$ & $\begin{array}{c}\text { Area } \\
\text { Excavated } \\
\left(\mathbf{m}^{2}\right)\end{array}$ & $\begin{array}{c}\text { Sieve } \\
\text { Size } \\
(\mathrm{mm})\end{array}$ & $\begin{array}{c}\text { Site } \\
\text { Reported }\end{array}$ & $\begin{array}{c}\text { Fish } \\
\text { Remains } \\
\text { Present }\end{array}$ & $\begin{array}{c}{ }^{14} \mathrm{C} \\
\text { Dated }\end{array}$ \\
\hline NE Moreton Island 1 & 1987 & I. Lilley & - & 0.5 & $6 / 3$ & $\mathrm{Y}$ & $\mathrm{N}$ & $\mathrm{Y}$ \\
\hline NRS 5 & 1983 & R. Neal & 182 & 1 & 3 & $\mathrm{~N}$ & - & $\mathrm{N}$ \\
\hline NRS 7 & 1983 & R. Neal & 754 & 0.75 & 3 & $\mathrm{Y}$ & $\mathrm{Y}$ & $\mathrm{N}$ \\
\hline NRS 8 & 1983 & R. Neal & 149450 & 6.75 & 3 & $\mathrm{Y}$ & $\mathrm{Y}$ & $\mathrm{Y}$ \\
\hline NRS 10 & 1983 & R. Neal & 5280 & 0.25 & 3 & $\mathrm{Y}$ & $\mathrm{Y}$ & $\mathrm{N}$ \\
\hline NRS 12 & 1983 & R. Neal & 2000 & 0.5 & 3 & $\mathrm{~N}$ & - & $\mathrm{N}$ \\
\hline NRS 14 & 1983 & R. Neal & 1800 & 1 & 3 & $\mathrm{~N}$ & - & $\mathrm{N}$ \\
\hline NRS 17 & 1983 & R. Neal & 500 & 2 & 3 & $\mathrm{~N}$ & - & $\mathrm{N}$ \\
\hline NRS 19 & 1983 & R. Neal & 18050 & 0.25 & 3 & $\mathrm{~N}$ & - & $\mathrm{Y}$ \\
\hline One-Tree & 1980 & J. Hall & 700 & - & $6 / 3$ & $\mathrm{~N}$ & - & $\mathrm{Y}$ \\
\hline Polka Point & $\begin{array}{c}1961-4 \\
-\end{array}$ & $\begin{array}{l}\text { D. Tugby } \\
\text { R. Neal }\end{array}$ & $\begin{array}{l}- \\
-\end{array}$ & - & $\begin{array}{l}- \\
-\end{array}$ & $\begin{array}{l}\mathrm{N} \\
\mathrm{N}\end{array}$ & $\begin{array}{l}- \\
-\end{array}$ & $\begin{array}{l}\mathrm{Y} \\
\mathrm{Y}\end{array}$ \\
\hline Saint-Smith Midden & 1994 & J. Hall & 60000 & 0.75 & $6 / 3$ & $\mathrm{Y}$ & $\mathrm{Y}$ & $\mathrm{Y}$ \\
\hline Sandstone Point & $\begin{array}{l}1972 \\
1984 \\
1985\end{array}$ & $\begin{array}{l}\text { L. Haglund } \\
\text { I. Walters } \\
\text { J. Hall }\end{array}$ & $\begin{array}{l}25000 \\
25000 \\
25000\end{array}$ & $\begin{array}{l}6.0 \\
0.5 \\
9.5\end{array}$ & $\begin{array}{l}- \\
3 \\
3\end{array}$ & $\begin{array}{l}\mathrm{Y} \\
\mathrm{Y} \\
\mathrm{Y}\end{array}$ & $\begin{array}{l}\mathrm{Y} \\
\mathrm{Y} \\
\mathrm{Y}\end{array}$ & $\begin{array}{l}\mathrm{Y} \\
\mathrm{Y} \\
\mathrm{Y}\end{array}$ \\
\hline Seary-Broutha Site & 1988 & I. McNiven & 600 & 0.5 & 3 & $\mathrm{Y}$ & $\mathrm{N}$ & $\mathrm{Y}$ \\
\hline St Helena Island & 1983 & G. Alfredson & 180 & 0.5 & 2 & $\mathrm{Y}$ & $\mathrm{Y}$ & $\mathrm{Y}$ \\
\hline Teewah Beach 5D & 1988 & I. McNiven & - & 7.5 & 3 & $\mathrm{Y}$ & $\mathrm{N}$ & $\mathrm{Y}$ \\
\hline Teewah Beach 18 & 1988 & I. McNiven & - & 0.75 & 3 & $\mathrm{Y}$ & $\mathrm{N}$ & $\mathrm{N}$ \\
\hline Teewah Beach 26 & 1988 & I. McNiven & 100 & 1.5 & 3 & $\mathrm{Y}$ & $\mathrm{Y}$ & $\mathrm{Y}$ \\
\hline Teewah Creek 112 & 1988 & I. McNiven & 140 & 0.5 & 3 & $\mathrm{Y}$ & $\mathrm{N}$ & $\mathrm{N}$ \\
\hline Tin Can Bay 75B & 1988 & I. McNiven & - & 0.5 & 3 & $\mathrm{Y}$ & $\mathrm{Y}$ & $\mathrm{Y}$ \\
\hline Toulkerrie & $\begin{array}{l}1978 \\
1985 \\
1989\end{array}$ & $\begin{array}{l}\text { J. Hall } \\
\text { I. Walters } \\
\text { J. Hall }\end{array}$ & $\begin{array}{l}- \\
- \\
-\end{array}$ & $\begin{array}{r}3.5 \\
2.5 \\
1.75\end{array}$ & $\begin{array}{c}6 / 3 / 1 \\
3 \\
3\end{array}$ & $\begin{array}{l}\mathrm{Y} \\
\mathrm{Y} \\
\mathrm{Y}\end{array}$ & $\begin{array}{l}\mathrm{Y} \\
\mathrm{Y} \\
\mathrm{Y}\end{array}$ & $\begin{array}{l}\mathrm{Y} \\
\mathrm{N} \\
\mathrm{Y}\end{array}$ \\
\hline Waddy Point 1 & 2001 & I. McNiven & 36 & 0.75 & 3 & $\mathrm{Y}$ & $\mathrm{Y}$ & $\mathrm{Y}$ \\
\hline Wallen Wallen Creek & 1985 & R. Neal & - & 4 & - & $\mathrm{Y}$ & $\mathrm{Y}$ & $\mathrm{Y}$ \\
\hline Webber Swamp 100 & 1988 & I. McNiven & - & 0.5 & 3 & $\mathrm{Y}$ & $\mathrm{N}$ & $\mathrm{Y}$ \\
\hline White Cliffs Sandblow 98 & 1988 & I. McNiven & 600 & 10 & 3 & $\mathrm{Y}$ & $\mathrm{N}$ & $\mathrm{N}$ \\
\hline White Patch Site 1 & 1973 & L. Haglund & - & 3 & - & $\mathrm{Y}$ & Y & $\mathrm{N}$ \\
\hline White Patch Site 2 & 1973 & L. Haglund & - & 3 & - & $\mathrm{Y}$ & $\mathrm{Y}$ & $\mathrm{N}$ \\
\hline White Patch Site 3 & 1973 & L. Haglund & 35 & 4.5 & - & $\mathrm{Y}$ & $\mathrm{Y}$ & $\mathrm{Y}$ \\
\hline White Patch Site 4 & 1973 & L. Haglund & - & 2 & - & $\mathrm{Y}$ & $\mathrm{N}$ & $\mathrm{N}$ \\
\hline White Patch Site 5 & 1973 & L. Haglund & - & 9 & - & $\mathrm{Y}$ & $\mathrm{N}$ & $\mathrm{N}$ \\
\hline
\end{tabular}




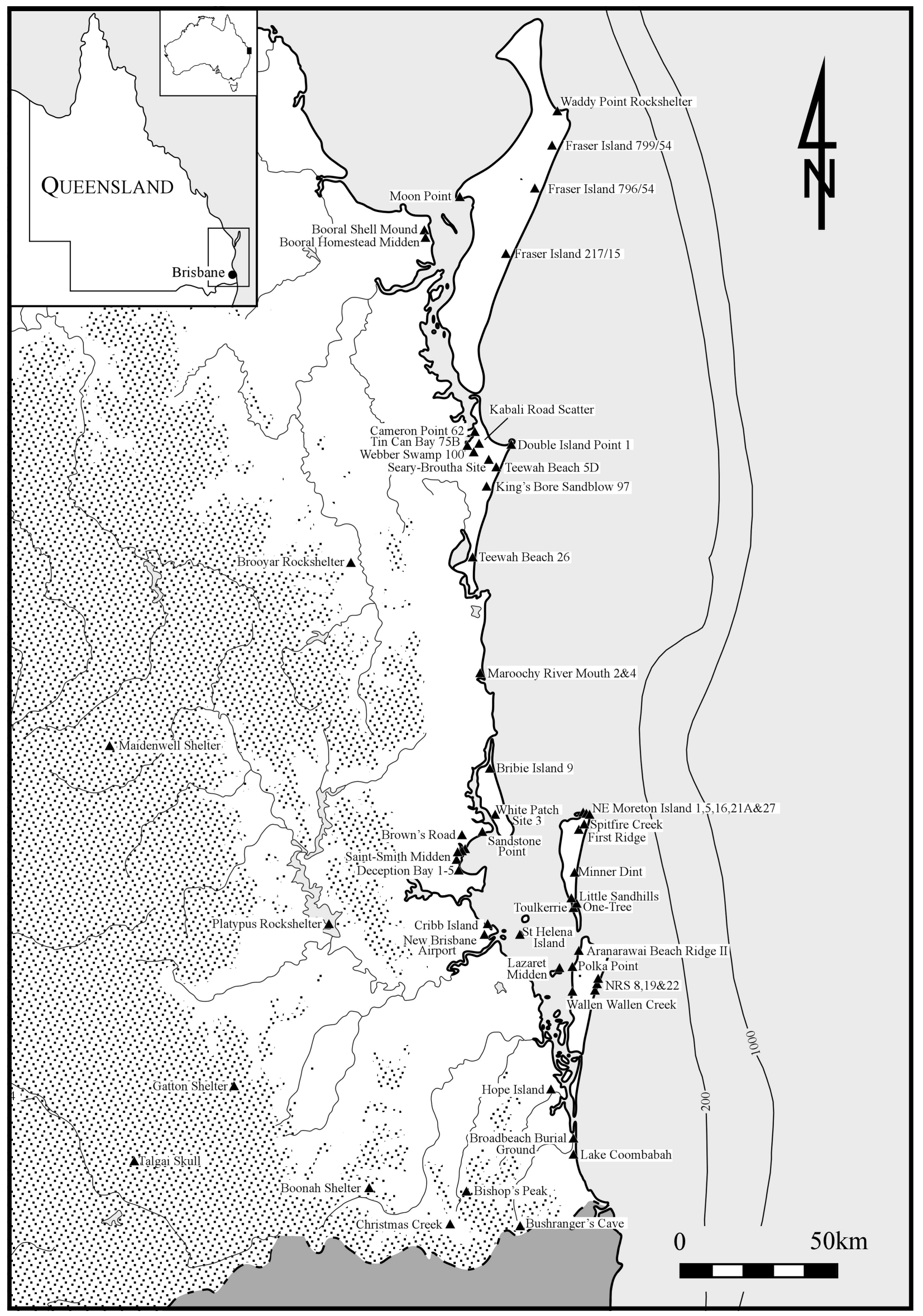

Figure 1. Southeast Queensland, showing dated archaeological sites. 


\section{Booral Shell Mound}

The Booral Shell Mound is part of an extensive middenfishtrap site complex on the western shores of Great Sandy Strait (Frankland 1990; see also Bowen 1998). A 50cm x $100 \mathrm{~cm}$ trench was excavated at the highest point of the mound as contiguous $50 \mathrm{~cm} \times 50 \mathrm{~cm}$ pits. The site was excavated in $25 \mathrm{~L}$ arbitrary units within stratigraphic units and sediments sieved through nested $5 \mathrm{~mm}$ and $2 \mathrm{~mm}$ screens. Results are available for one of the pits (Square A). The site was occupied shortly before 2,950 $\pm 60 \mathrm{BP}$ (Beta-32046, charcoal) ${ }^{1}$. Frankland (1990) identified a total of 1,470 NISP (number of identified specimens) of fish bone and an MNI (minimum number of individuals) of 36 . Although large numbers of fish remains from a variety of species are evident from the base of the deposit, rates of fish bone discard clearly decrease through time (Figure 2).

\section{Bribie Island 9}

Bribie Island 9 is a large (c. $\left.500,000 \mathrm{~m}^{2}\right)$ midden complex on the northern end of Bribie Island (Hall 1991, 1999; Smith 1992; cf. Hall [1999:174] who cites area as 10,000m²). Few details about the excavation have been published. According to Hall (1999:174; see also Hall 1991), the site contains 'fish and other vertebrate bone' although further abundance details are not presented. Although the site is dated to 3,280 $\pm 80 \mathrm{BP}$ (Beta-56566, charcoal), fish remains only occur in the top of the deposit dated to $200 \pm$ 80 BP (Beta-56565, charcoal) (J. Hall, School of Social Science, University of Queensland, pers. comm., 2002).

\section{Broadbeach Burial Ground}

The Broadbeach site is a large burial complex near the Nerang River on the Gold Coast. Haglund (1976) excavated a total of $228 \mathrm{~m}^{2}$ at the site. Eight radiocarbon dates bracket use of the site from 1,390 \pm 100 BP (ANU$68 / 2$, charcoal) to $50 \pm 86 \mathrm{BP}$ (V-161, charcoal) (Ulm and Reid 2000). As the excavation was focussed on obtaining Aboriginal skeletal material for comparative anatomical studies (e.g. Murphy 1991), little attention was given to the recovery and analysis of associated cultural materials. Some faunal material was identified by Bartholomai (1976). Fish remains were apparently recovered from throughout the deposit and all diagnostic elements were identified as belonging to the Family Sparidae. Only 34 individual fish bone elements were identified, consisting mainly of vertebrae.

\section{Cameron Point Site 62}

This large shell midden was exposed in an erosion face on the eastern shores of Tin Can Bay (McNiven 1990a:200$209,1991 \mathrm{~b})$. Three $50 \mathrm{~cm} \times 50 \mathrm{~cm}$ pits were excavated immediately behind the eroding section, one of which (Square B) has been reported. There is a marked vertical discontinuity in the distribution of cultural material, with faunal remains restricted to the top $17 \mathrm{~cm}$ of the deposit and the last $190 \pm 50$ (Beta-34400, charcoal) years. All stone artefacts lie below this upper level. A total of $0.15 \mathrm{~g}$ of fish bone was recovered from the upper level (XU2, 4 and 5). An otolith $(0.10 \mathrm{~g})$ from a summer whiting (Sillago ciliata) was the only specimen identified. McNiven (1990a:206) cautioned that the fish may have been deposited by dingoes as 'dingo faeces exhibiting fish bones have been observed on the surface adjacent to the site'.

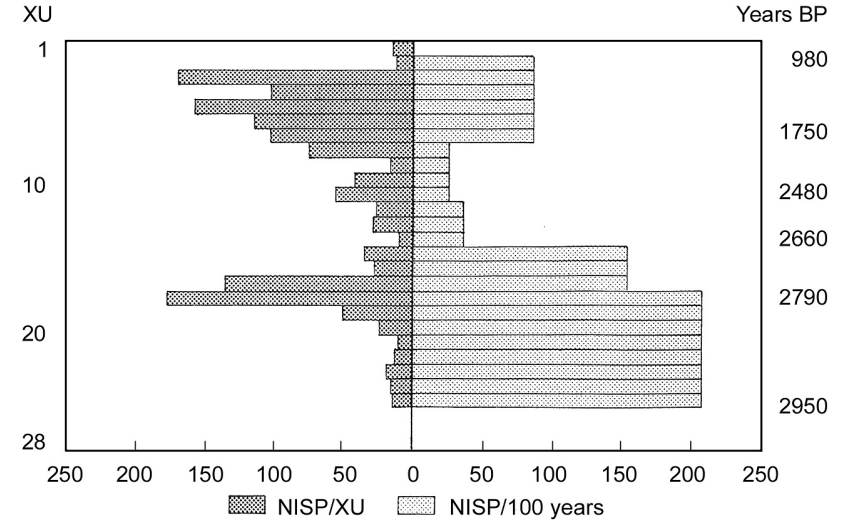

Figure 2. Number of identified specimens (NISP) of fish remains by excavation unit and 100 year interval, Booral Shell Mound, Square A (Frankland 1990:58).

\section{Double Island Point Site 1}

Double Island Point Site 1 is a large shell and stone artefact scatter in an active sandblow $500 \mathrm{~m}$ south of Double Island Point (McNiven 1990a:130-141, 1991c). An excavation covering $11.5 \mathrm{~m}^{2}$ was undertaken to exhume two Aboriginal burials. Fish remains accounted for $0.31 \mathrm{~g}$ of the faunal assemblage, including a single MNI of tarwhine (Rhabdosargus sarba). The site is dated to $160 \pm 90 \mathrm{BP}$ (Beta-34059, charcoal).

\section{First Ridge 19B}

This site is one of a number of small discrete shell heaps occurring in northeast Moreton Island (Robins 1983, 1984). A $50 \mathrm{~cm} \times 50 \mathrm{~cm}$ pit was excavated at one of these sites (19B) in two 10cm-deep excavation units. All sediment was sieved through $6 \mathrm{~mm}$ and $3 \mathrm{~mm}$ screens. Recoveries consisted almost entirely of pipi (Donax deltoides), with some charcoal and a single whiting otolith. A date of 1,150 \pm 70 BP (Beta-1946) was obtained on a shell sample.

\section{King's Bore Sandblow 97}

King's Bore is an extensive stone artefact scatter covering some $10,000 \mathrm{~m}^{2}$ within a large active sandblow about $250 \mathrm{~m}$ inland from Teewah Beach (McNiven 1985, 1990a, 1992a). A total area of $111 \mathrm{~m}^{2}$ was excavated to a depth of $5 \mathrm{~cm}$, yielding $5,265 \mathrm{~g}$ of stone artefacts and $1.22 \mathrm{~g}$ of shellfish and fish remains with some fragments identified as pipi (Donax deltoides) and summer whiting (Sillago ciliata). A further $10 \mathrm{~m}^{2}$ was subjected to controlled excavation to investigate in situ deposits, resulting in the recovery of a further $1.38 \mathrm{~g}$ of pipi fragments and unidentified fish bone and scale fragments from the surface and $138 \mathrm{~g}$ of stone artefacts. Although a date of 3,560 \pm 100 (Beta-25510, charcoal) was obtained from the in situ deposit, all of the recovered faunal remains are argued to be derived from modern carnivore activity on the basis of their good preservation and the presence of flesh on some shell and bone fragments (McNiven 1990a, 1990b, 1992a). Fish bone was also noted as a component of a desegregating dingo scat on the site.

\section{Lazaret Midden}

The Lazaret Midden is located on the northeast margin of Peel Island in southern Moreton Bay (Ross 2001; Ross and 
Coghill 2000; Ross and Duffy 2000). Four $50 \mathrm{~cm} \mathrm{x} 50 \mathrm{~cm}$ pits have been excavated, two of which have been analysed and await full publication. Material was sieved through $6 \mathrm{~mm}, 3 \mathrm{~mm}$ and $1 \mathrm{~mm}$ mesh. The age of the midden ranges from c. 1,200 BP at the base to modern at the top. Ross and Coghill (2000:81) report that there 'is abundant fish bone in the site at all levels, particularly in the $1 \mathrm{~mm}$ fraction'. Ross and Duffy (2000:37) report that $0.1-0.5 \%$ of each $100 \mathrm{~g}$ sample of the $1 \mathrm{~mm}$ sieve residue consists of bone, 'particularly fragmented fish spines' and that $50 \mathrm{~g}$ of fish bone was recovered from the $1 \mathrm{~mm}$ sieve from a single square. On the basis of extrapolation, Ross and Duffy (2000:38) suggest that the total fish bone in this square is in excess of $150 \mathrm{~g}$ and that this is more than twice the weight of fish bone excavated from any other Moreton Bay site.' Recently, Ross (2001) reported that 'fish bone found in the Lazaret Midden represents almost 60,000 NISP (weighing almost $250 \mathrm{~g}$ ) from just one $50 \mathrm{~cm} \times 50 \mathrm{~cm}$ pit.' A major problem here is the fact that most of the 60,000 NISP reported are not actually identified specimens or elements, but rather 'fragmented fish spines' (Ross and Duffy 2000:37) yielded by the 'use of a $1 \mathrm{~mm}$ sieve for fish bone recovery' (Ross 2001). In the absence of other relative abundance measures (e.g. MNI) it is difficult to evaluate the significance of this site for understanding regional fishing patterns.

\section{Little Sandhills}

Little Sandhills is an extensive shell midden and stone artefact scatter located in active sand dunes on southern Moreton Island (Robins 1983, 1984). Excavations were conducted over the entire surface of the site, some $90 \mathrm{~m}^{2}$, to a depth of $5 \mathrm{~cm}$. Excavations included the total recovery of 10 small piles of shell. Excavated sediment was sieved through $6 \mathrm{~mm}$ and $3 \mathrm{~mm}$ screens. The combined assemblage consisted of shellfish remains (mostly Donax deltoides) and stone artefacts, as well as small amounts of fish bone and other bone fragments tentatively identified as dugong (Dugong dugon). Fish remains included 18 diagnostic skeletal elements from Sparidae and whiting with some mullet scales. A radiocarbon date obtained on shell returned a result of 102.1 $\pm 7 \%$ BP modern (Beta-1945), indicating probable post-contact occupation.

\section{Minner Dint}

Minner Dint is a discontinuous shell midden exposed in a truncated foredune on the east coast of Moreton Island (Hall 1980). Two $1 \mathrm{~m} \times 2 \mathrm{~m}$ trenches (A and B) were excavated, yielding a near-basal age of $520 \pm 75$ BP (I11095, charcoal) from Trench B. Excavation followed natural stratification and all sediment was sieved through 1/8 inch (3.175mm) mesh (Hall 1980:100), not only 1/4 inch $(6.35 \mathrm{~mm})$ mesh as Walters $(1979: 37)$ stated. The deposit was dominated by pipi (Donax deltoides), which comprised over $99 \%$ by weight of the entire faunal assemblage. Small amounts of fish, marine snail (Conuber sp.) and cockle (Anadara sp.) remains were also found. Table 2 is a corrected version of Hall's (1980:105) Table 2 , which used the weight of pipi fragments rather than total pipi weight from his Table 5 (Hall 1980:106). Walters (1986:180) also used the erroneous version. The vertebrate faunal assemblage consisted entirely of fish remains, representing eight identified species. A total of 190 fish
Table 2. Weights and percentages of faunal categories from Minner Dint (Hall 1980:105-106).

\begin{tabular}{|l|r|r|r|c|}
\hline Category & \multicolumn{1}{|c|}{$\begin{array}{c}\text { Trench A } \\
\text { Weight } \\
\text { (g) }\end{array}$} & \% & \multicolumn{1}{c|}{$\begin{array}{c}\text { Trench B } \\
\text { Weight } \\
\text { (g) }\end{array}$} & $\%$ \\
\hline Fish Bone & 1.55 & $<0.01$ & 22 & 0.02 \\
\hline Pipi & 67757 & 99.99 & 110107 & 99.91 \\
\hline Snail & 8.26 & 0.01 & 69.5 & 0.06 \\
\hline Cockle & - & - & 2.3 & $<0.01$ \\
\hline
\end{tabular}

NISP were counted. All 22g of identified fish bone from Trench B occurred in Spit 3,10-15cm below the surface (Walters 1979:40). Despite the small quantity of fish remains recovered and their restriction to a small area of the excavated deposit, Hall (1999:176, my emphasis) interprets the site 'as a camp relating to fishing and shellfish gathering which was repeatedly visited for short periods of time'.

\section{New Brisbane Airport}

The New Brisbane Airport site is located on a palaeoshoreline in a prograded section of the Brisbane River delta, some $5 \mathrm{~km}$ from the modern shoreline (Hall and Lilley 1987). The site was excavated on four separate occasions, yielding evidence for human occupation before $4,830 \pm 110$ BP (Beta-33342, charcoal; Ulm and Hall 1996). Hall reported 'significant' (1990:180) and 'fragmentary fish bone' (1999:174) dating to the midHolocene encased in the ironstone conglomerate matrix of the lower excavation units, although quantification of the remains has not been attempted. Walters (1992c:35) noted that only a few fragments of fish bone were recovered and argues that these have not been demonstrated to be cultural. Stratigraphic and other details published to date do not provide a clear cultural context for the fish remains.

\section{NRS 7, 8 and 10}

These three sites are located on the central east coast of North Stradbroke Island and form part of the Blue Lake Creek site complex (Neal 1984). 'NRS' is an acronym for 'Norma Richardson Site' (Neal 1984:29).

NRS 7 covers an estimated area of $754 \mathrm{~m}^{2}$ and is located on a high frontal dune $225 \mathrm{~m}$ south of Blue Lake Creek and $50 \mathrm{~m}$ west of Eighteen Mile Swamp. Neal (1984) excavated three contiguous $50 \mathrm{~cm} \times 50 \mathrm{~cm}$ pits at the site. Although culturally-sterile deposits were not reached, the upper units appear to contain the densest cultural material. Pipi (Donax deltoides) comprised over $99 \%$ by weight of the total assemblage. The remainder included occasional other shells such as oyster (Saccostrea glomerata), whelk (Pyrazus ebeninus) and hairy mussel (Trichomya hirsuta) with smaller amounts of stone artefacts and bone. A total NISP of 126 for fish remains from the site was counted by Walters (1986:233), although it is unclear whether these remains derive from only one or from all three pits excavated (Figure 3 ).

NRS 8 is an extensive midden $\left(149,450 \mathrm{~m}^{2}\right)$ located in a large swale behind high dunes to the south of Blue Lake 


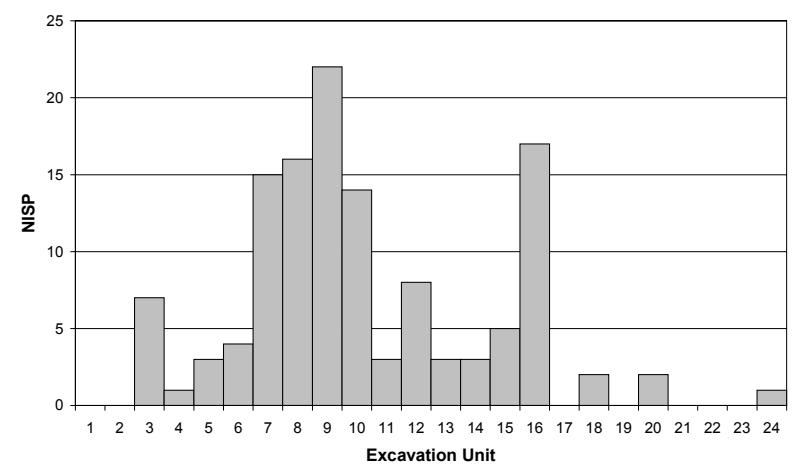

Figure 3. Number of identified specimens (NISP) of fish remains by excavation unit, NRS 7 (after Walters 1986:341).

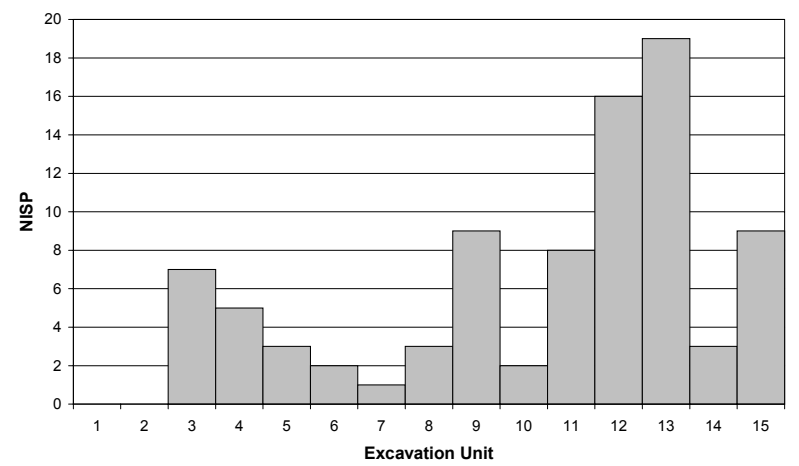

Figure 4. Number of identified specimens (NISP) of fish remains by excavation unit, NRS 10 (after Walters 1986:342; cf. 1986:349).

Creek (Richardson 1984:28-29). Neal (1984) excavated some $6.75 \mathrm{~m}^{2}$ at the site in a series of $50 \mathrm{~cm}$ squares. Walters (1986:233) reported a total NISP of 61 for fish remains derived from four of these excavated pits (i.e. an average of c. 15 NISP per $50 \mathrm{~cm} \times 50 \mathrm{~cm}$ pit). Data on the vertical distribution of fish remains are not reported. Richardson (1984) obtained a date of $470 \pm 60$ BP (ANU3336, marine shell) from an auger sample at this site.

NRS 10 covers an area of some $5,280 \mathrm{~m}^{2}$ to the north of the confluence of Blue Lake Creek and Eighteen Mile Swamp (Richardson 1984:28-29). A single 50cm x 50cm pit was excavated. The gross composition of the deposit is similar to other NRS sites, with pipi (Donax deltoides) dominating the faunal remains. Walters (1986:233) identified a total of 87 fish NISP (but note there is an unexplained discrepancy of four fish NISP between the total of 87 presented in Table A4 [Walters 1986:342] and the 91 in Table A11 [Walters 1986:349]; see Figure 4).

Excavated material from all three sites was sieved through $3 \mathrm{~mm}$ mesh. Although no dates are available for the controlled excavation pits, Walters $(1989,1992 a)$ stated that they are of a similar antiquity to marine shell from auger samples taken in this general area which indicate that the entire site complex dates to the last 200 years (see Richardson 1984).

\section{Saint-Smith Midden}

The Saint-Smith site is an extensive shell midden deposit on the shores of Deception Bay near the mouth of the
Caboolture River (Hall 1995). In addition to an extensive program of auguring to define the subsurface extent of the deposit, three $50 \mathrm{~cm} \times 50 \mathrm{~cm}$ test pits were excavated in $10 \mathrm{~L}$ units and sediment was sieved through $6 \mathrm{~mm}$ and $3 \mathrm{~mm}$ screens. Hall (1995:13) noted significant disturbance in one of these pits (TP1), and excluded it from analysis. Occupation spans the last 1,000 years, with a near-basal date of $930 \pm 60 \mathrm{BP}$ (Wk-3423, charcoal). The cultural assemblage was dominated by shellfish remains with lesser quantities of stone artefacts and bone. Fish remains were recovered from all pits and are associated with shell material. A total of $7.5 \mathrm{~g}$ of fish bone was recovered from TP2 and 33g from TP3, although no data are presented for the vertical distribution of fish remains in the deposit.

\section{Sandstone Point}

Sandstone Point is an extensive midden complex covering an area of some $25,000 \mathrm{~m}^{2}$ on a series of beach-ridges on the foreshore of Deception Bay. The site was originally excavated by Haglund (1974; see also Crooks 1982) who recovered a variety of shellfish remains with some terrestrial and marine mammal bone and fish remains. Charcoal samples returned radiocarbon ages of $620 \pm 95$ BP (SUA-478) and $780 \pm 95$ BP (SUA-479; Crooks 1982:37). Walters (1986:202-209) excavated a further two contiguous $50 \mathrm{~cm} \times 50 \mathrm{~cm}$ pits at the site (SSP 1-A and 1-B) adjacent to 'the most promising looking exposure' (Walters 1986:204). Two charcoal samples from close to the middle and base of this deposit returned radiocarbon values of 500 $\pm 50 \mathrm{BP}$ (SUA-2358) and $740 \pm 50 \mathrm{BP}$ (SUA-2357) respectively (Walters 1986:204). Owing to time constraints, only the first four excavation units (out of 37) of one of the pits (SSP 1-A) were analysed in Walters' (1986) original study. Despite this small sample size, however, Walters $(1986: 209,233)$ extrapolated the NISP data to give a figure of some $46,000 \mathrm{NISP} / \mathrm{m}^{3}$. Contrary to Frankland's (1990:62) assertion, full NISP data for SSP 1A are presented by Nolan (1986:85) who reports a total of $35,883 \mathrm{NISP}$ or $101,796 \mathrm{NISP} / \mathrm{m}^{3}$ (Figure 5).

Hall (see Nolan 1986) excavated a further $38(50 \mathrm{~cm} \mathrm{x}$ $50 \mathrm{~cm}$ ) pits at the site in 1985 . Unlike previous excavations, which were all on the frontal dune, these were distributed over the entire site complex. Analysis of assemblages from four of these by Nolan (1986) revealed marked intra-site variability in the distribution and age of cultural material, particularly fish bone (Figure 6).

\section{St Helena Island}

The St Helena Island site is an extensive midden (c. $\left.900 \mathrm{~m}^{3}\right)$ in the southwest of St Helena Island in Moreton Bay located approximately $6 \mathrm{~km}$ east of the mouth of the Brisbane River (Alfredson 1983, 1984a, 1984b). Two 50cm $\mathrm{x} 50 \mathrm{~cm}$ pits were excavated. Only one of the pits has been analysed. About $75 \%$ of the excavated material was sieved through $2 \mathrm{~mm}$ mesh, while the remainder was mechanically dry-sieved in nested Endicott sieves ranging from $125 \mu \mathrm{m}$ to $16 \mathrm{~mm}$ mesh. Of the sieve residue, only about $75 \%$ of material smaller than $4 \mathrm{~mm}$ was sorted owing to the limitations of time and identifiability. Two shell samples returned radiocarbon ages of 1,370 $\pm 60 \mathrm{BP}$ (Beta-6140) for XU9 and a non-basal 2,240 $\pm 70 \mathrm{BP}$ (Beta-6141) for XU13. Alfredson (1984a:74) used a depth-age curve to extrapolate a basal age for the site of about 2,700 BP. 


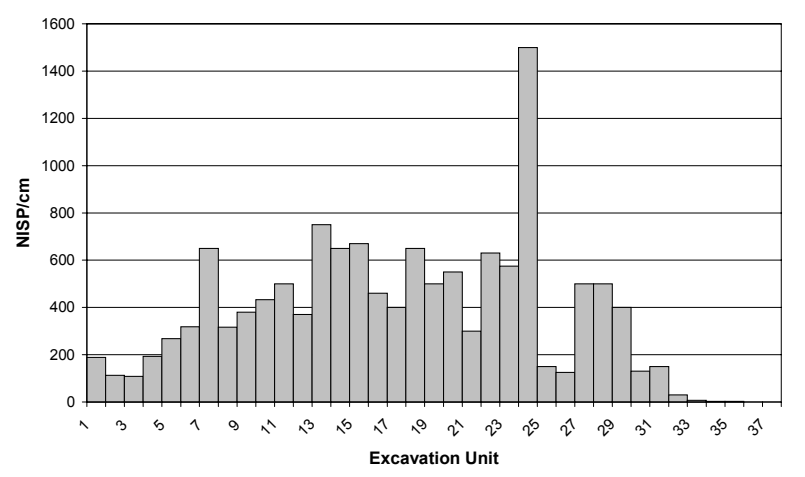

Figure 5. Number of identified specimens (NISP) of fish remains by vertical centimetre of deposit by excavation unit, Sandstone Point 1-A (after Nolan 1986:85).

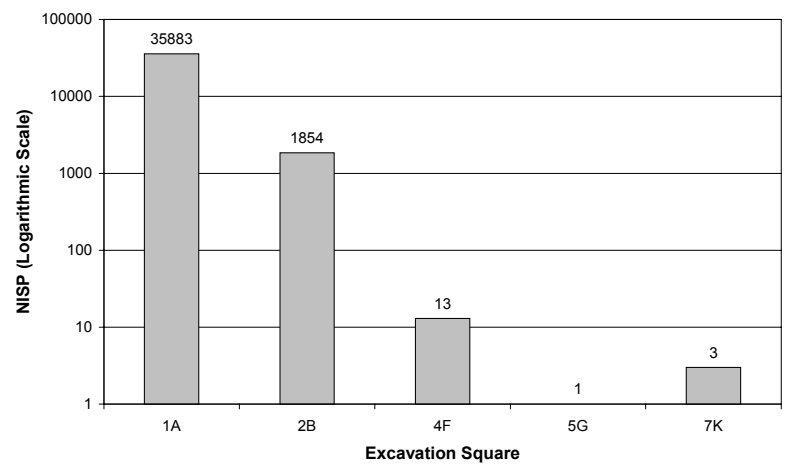

Figure 6. Comparison of abundance of fish remains at Sandstone Point where NISP data available (Nolan 1986:85-88).

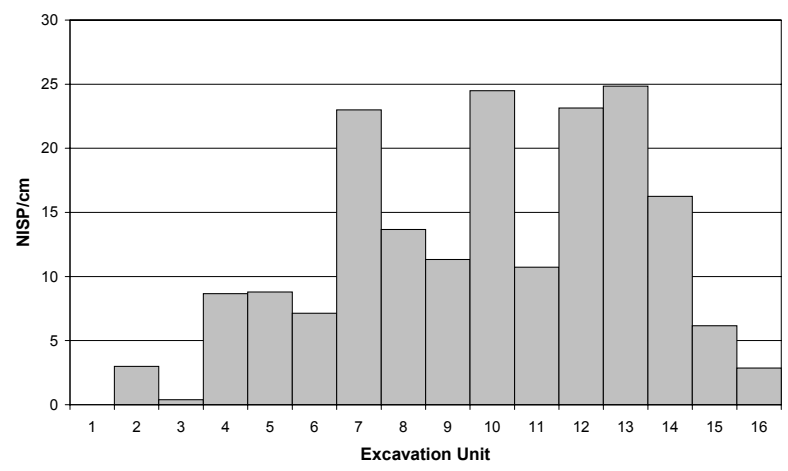

Figure 7. Number of identified specimens (NISP) of fish remains per vertical centimetre of deposit by excavation unit, St Helena Island, Test Pit 1 (after Walters 1986:343; cf. Alfredson 1984a:63).

The faunal assemblage was volumetrically dominated by rock oyster (Saccostrea glomerata), hairy mussel (Trichomya hirsuta) and mud whelk (Pyrazus ebeninus). Fruit bat (Pteropus poliocephalus) was present throughout, as were fish (Figure 7), with seven species identified. Walters (1986:350) calculated a total of 576 NISP. Smaller amounts of mud crab (Scylla serrata) shell and dugong (Dugong dugon), turtle and lizard bone were also recovered. Both fish and fruit bat bone constituted a much greater proportion of the faunal assemblage in the lower half of the deposit, although no attempt was made to quantify the bat bone owing to extensive fragmentation (Alfredson 1984b:4).

Alfredson (1984a:73) interpreted material from Excavation Units 2 to 5 as disturbed nineteenth century quarry spoil. Even if one disregards this material, there is a general trend towards the diminution of the quantity of fish remains towards the surface of the deposit, a fact which Walters (1986:244) could not attribute to diagenetic bone loss. As there are only two radiocarbon dates from the sequence it is difficult to construct temporal analytical units for this site (see Frankland 1990).

\section{Teewah Beach Site 26}

Teewah Beach Site 26 is a large midden site $8 \mathrm{~km}$ north of the Noosa River (McNiven 1990a:96-109). A $1.5 \mathrm{~m}^{2}$ pit was excavated using arbitrary $5 \mathrm{~cm}$ units within stratigraphic units. All sediments were sieved through $3 \mathrm{~mm}$ mesh. Five radiocarbon dates were obtained on charcoal, ranging from $4,780 \pm 80 \mathrm{BP}$ (Beta-25512) to $340 \pm 70 \mathrm{BP}$ (Beta-30401). The combined assemblage was dominated by shellfish remains (and Donax deltoides in particular) with lesser amounts of stone artefacts, charcoal and some fish bones. A total of $1.73 \mathrm{~g}$ of fish bone yielded an MNI of one. Four posterior molars identified as tarwhine (Rhabdosargus $s a r b a)$ were the only diagnostic fragments. All fish remains were associated with the upper shell deposit which dates to the last 1,000 years.

\section{Tin Can Bay Site 75B}

This site is exposed in an erosion face on the west coast of Tin Can Bay. McNiven (1990a:191-200, 1991b) excavated two contiguous $50 \mathrm{~cm} \times 50 \mathrm{~cm}$ pits. The base of the midden is dated on shell at $700 \pm 70 \mathrm{BP}$ (Beta-19421), producing a calibrated age of 309 cal BP (probably mid-seventeenth century and not modern as McNiven [1990a:194] inferred). Cultural material consisted primarily of shellfish remains, stone artefacts and a minute quantity of fish bone ( $0.01 \mathrm{~g}$ of unburnt bone). McNiven suggested again that dingos and not humans were responsible for deposition of the fish material.

\section{Toulkerrie}

Toulkerrie is an extensive midden complex situated on low sand ridges on the southwest coast of Moreton Island. The site was initially investigated by Hall (1984) in six $50 \mathrm{~cm} \mathrm{x}$ $50 \mathrm{~cm}$ pits and a $2 \mathrm{~m} \times 1 \mathrm{~m}$ trench, some of which were later extended. Excavation was conducted in $5 \mathrm{~cm}$ units and material wet sieved through nested $6 \mathrm{~mm}, 3 \mathrm{~mm}$ and $1 \mathrm{~mm}$ screens (J. Hall, School of Social Science, University of Queensland, pers. comm., 1995; due to a typographical error, Hall [1984:64] incorrectly reported 8mm mesh as the larger of the two grades used for sieving, and Walters [1986:181] restated this erroneous figure despite reporting the correct one in a previous work [Walters 1979:38]). A single radiocarbon determination on charcoal obtained close to the base of the cultural deposit returned an age of $370 \pm 75$ BP (I-11096). Fish remains were found to dominate the vertebrate faunal assemblage $(95 \%$ by weight), with a minimum of 204 individuals from 10 species identified from the coarse screen fraction alone from Trenches 4 and 6 (Hall 1984). Bream (Acanthopagrus australis), tarwhine (Rhabdosargus sarba) and mullet (Mugil cephalus) were the dominant taxa. 


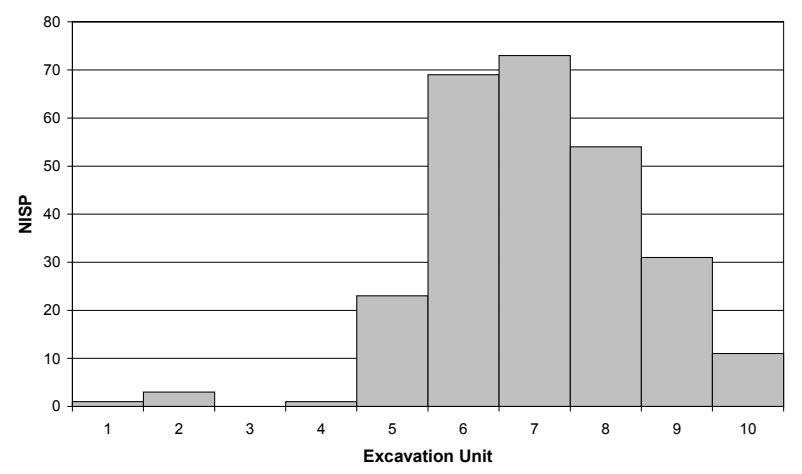

Figure 8. Number of identified specimens (NISP) of fish remains by excavation unit, Toulkerrie W9A (after Walters 1986:339).

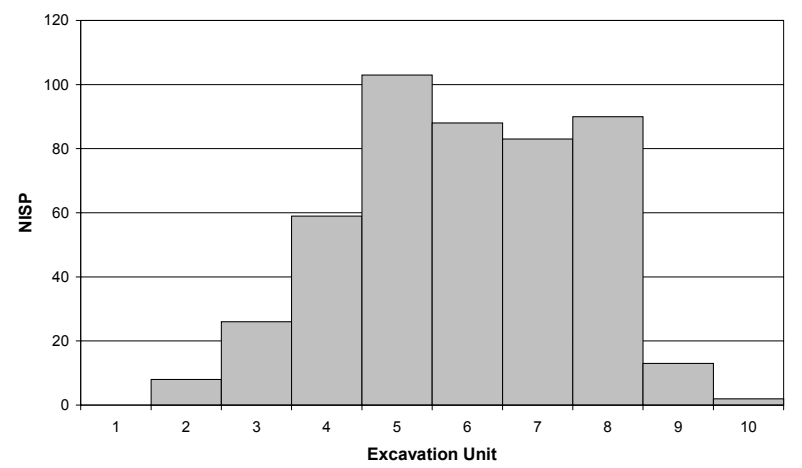

Figure 9. Number of identified specimens (NISP) of fish remains by excavation unit, Toulkerrie W9B (after Walters 1986:340).

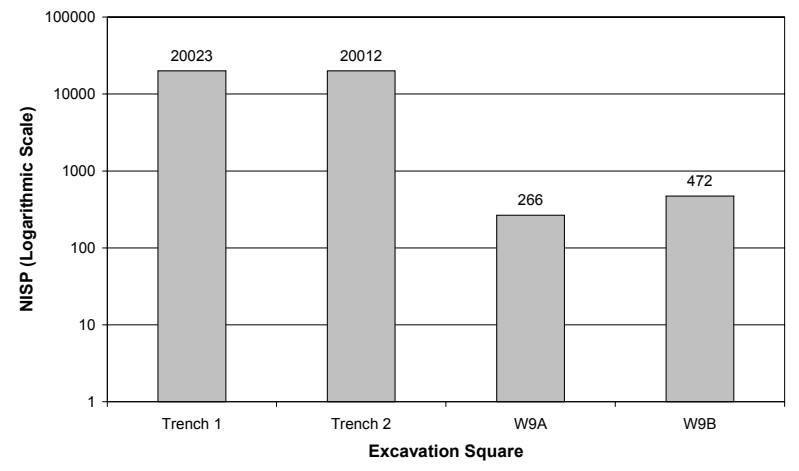

Figure 10. Comparison of abundance of fish remains at Toulkerrie where NISP data available (after Hall and Bowen 1989; Walters 1986).

As part of his doctoral research, Walters (1986:189193) excavated 10 more $50 \mathrm{~cm} \times 50 \mathrm{~cm}$ pits adjacent to Hall's Trench 6 in order to expand the fish sample. All the deposit was wet sieved through $3 \mathrm{~mm}$ mesh. While no radiocarbon determinations were obtained, Walters assumed contemporaneity of his deposit with the nearby pits excavated by Hall (1984). This chronological assumption is problematic because Walters' excavations were at least $20 \mathrm{~m}$ away from the pit that yielded the $370 \pm$ $75 \mathrm{BP}$ date. The only other indication of the antiquity of his deposits is a number of European artefacts in the top $5 \mathrm{~cm}$ of Trench 6 (Hall 1984:68). Walters (1986:339-340) only presents NISP fish data for two pits - W9A and W9B (Figures 8,9). Walters identified a total $57 \mathrm{MNI}$ of fish for both trenches.

Hall and Bowen (1989; see also Bowen 1989) excavated a further seven $50 \mathrm{~cm} \times 50 \mathrm{~cm}$ pits about $100 \mathrm{~m}$ south of the original excavation. Sediment was wet sieved through $3 \mathrm{~mm}$ screens. Only three of these pits have been analysed and reported. Fish dominate the vertebrate faunal assemblage with four species identified in the preliminary analysis: bream (Acanthopagrus australis), tarwhine (Rhabdosargus sarba), snapper (Chrysophrys auratus) and whiting (Sillago sp.). Significantly, low rates of fish bone deposition are evident from the earliest use of the site some time before 2,290 \pm 80 BP (Beta-32047, charcoal), although the highest concentrations of fish remains are located in the upper unit which also contains abundant shellfish remains. Hall and Bowen (1989) calculated 20,023 NISP for Trench 1 and 20,012 NISP for Trench 2 (Figure 10).

Figure 10 clearly illustrates significant variation in the density of fish remains across the Toulkerrie site. This intra-site variation has not been taken into account in interpreting fish remains abundance at the site and should act as a caution against extrapolating from small test pits to entire sites (cf. Hall and Bowen 1989:14-15).

\section{Waddy Point 1 Rockshelter}

Waddy Point 1 Rockshelter is a small shelter on the southern end of the Waddy Point headland on Fraser Island. A $1.5 \mathrm{~m} \times 0.5 \mathrm{~m}$ trench was excavated as contiguous $50 \mathrm{~cm} \times 50 \mathrm{~cm}$ squares to a maximum depth of $182 \mathrm{~cm}$ (McNiven et al. 2002). Sediments were dry sieved through $3 \mathrm{~mm}$ mesh. Preliminary results are only available for Square A, the one least disturbed by animal burrowing. Recovered material includes charcoal $(808.8 \mathrm{~g})$, shell $(10,304.1 \mathrm{~g})$, bone $(148.5 \mathrm{~g})$ and stone artefacts $(17.2 \mathrm{~g})$. The distribution of bone in Square A is presented in Figure 11. Note that although the bone data are dominated by fish, they also include some bird and mammal bone. A few larger mammal bones occur, including the mandible of a northern brown bandicoot, suggesting that the proportion of fish bone in the total weight reported is relatively low. The base of the shell deposit containing the recovered fish bone is dated to $1,050 \pm 50$ (OZF-556; charcoal), although stone artefacts continue to the base of the excavation indicating that basal cultural deposits were not reached.

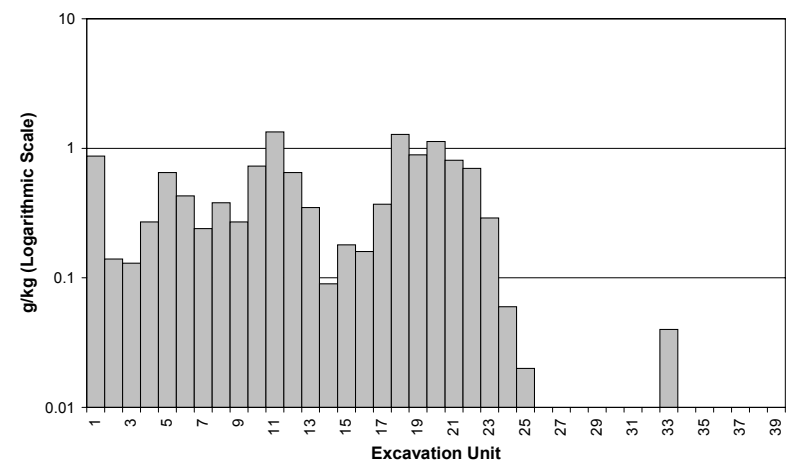

Figure 11. Comparison of abundance of all bone by excavation unit, Waddy Point 1 Rockshelter, Square A (after McNiven et al. 2002). 


\section{Wallen Wallen Creek}

Wallen Wallen Creek is an open midden site located about $400 \mathrm{~m}$ inland from the present west coast of North Stradbroke Island (Neal and Stock 1986). The site represents the earliest evidence for human occupation in southeast Queensland, with 20 radiocarbon dates spanning from $21,800 \pm 400 \mathrm{BP}$ (OxA-806, charcoal) to $1,070 \pm 50$ BP (SUA-2461, marine shell) (Gowlett et al. 1987; Neal and Stock 1986:619). Faunal remains are restricted to the upper deposit, which is dated to the last c.4,000 years (cf. Ross and Duffy [2000:22] who claim the site 'demonstrates that marine exploitation ... has been the dominant subsistence activity at the site from 20,000 B.P. to the present' - at the glacial maximum the site was located $30-40 \mathrm{~km}$ inland of the coast and is therefore unlikely to have been close to abundant marine and littoral resources). A total of four $1 \mathrm{~m}$ squares were excavated, although results from only two of these (WWC-X/Z and WWC-M28-B) have been reported (Neal and Stock 1986; Walters 1986). Details of fish remains are only available for square WWCM28-B (Walters 1986).

Although radiocarbon dates are not available for WWC-M28-B, dates reported for adjacent squares are $1,520 \pm 70$ BP (SUA-2236) on shell from 49-56cm depth, $9,810 \pm 130 \mathrm{BP}$ (SUA-2251) on charcoal from 136-141 cm depth, and 17,500+900/-800 BP (SUA-2235) on charcoal from 189-200cm depth. Neither Neal and Stock (1986) nor Walters (1986) related the excavation units to measurements of depth, although Neal (Queensland Environmental Protection Agency, pers. comm., 1995) indicated that fish remains in this sequence are restricted to the last 3,000 years. Significantly, Walters' (1986) own analysis revealed decreasing rather than increasing fish discard at the site though time, a fact he could not attribute to diagenetic bone loss (Walters 1986:244; Figure 12).

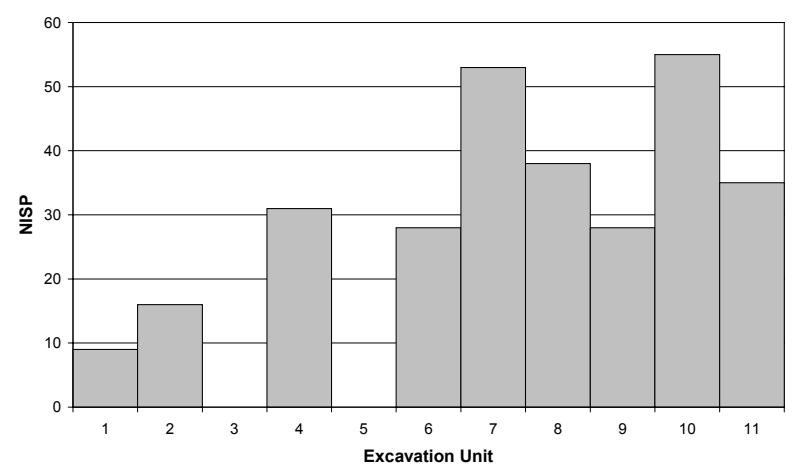

Figure 12. Number of identified specimens (NISP) of fish remains by excavation unit, Wallen Wallen Creek, M28-B (after Walters 1986:246).

\section{White Patch Site 3}

This site is one of a number excavated by Haglund (see Crooks 1982:60-74) on the southwest coast of Bribie Island. Haglund excavated an area of c. $4.5 \mathrm{~m}^{2}$ at Site 3 which yielded a large faunal assemblage dominated by whelk (Pyrazus ebeninus), cockle (Anadara sp.), oyster (Saccostrea glomerata) and mussel (Trichomya hirsuta). Although many of the fish remains were not speciated owing to fragmentation, 35 skeletal elements were identified to species level, these being mainly bream (Acanthopagrus australis) and tarwhine (Rhabdosargus sarba), but including a single element of the fork-tailed catfish (Arius sp.). Crooks (1982:64) noted a concentration of fish bone in Square B52 representing about 14 bream, $10-15 \mathrm{~cm}$ below the surface. Two dates of $450 \pm 95 \mathrm{BP}$ (SUA-480) and $670 \pm 95$ BP (SUA-481) were obtained on charcoal samples from Square C50.

\section{Summary}

The regional data relating to the representation of fish remains in coastal sites are summarised in Table 3. Clearly, fish remains are a rare component in southeast Queensland faunal assemblages. Only five sites contain more than 300 NISP, the minimum limit suggested by Amorosi et al. (1996) for assemblages to be used in inter-site comparisons. The overall picture presented by these 23 sites is one of considerable variability and the absence of any general directional trend towards intensifying marine fish production. Of the eight sites originally used by Walters', three (NRS 7, 8 and 10) probably date to the post-contact period and should not necessarily be considered as representative of pre-European Aboriginal lifeways, two (Wallen Wallen Creek and St Helena Island) actually exhibit decreases in the rate of fish discard over the last 1,000 years which Walters (1986) himself could not attribute to taphonomic factors, and one site (Minner Dint) has virtually all recovered fish remains from a single excavation unit. Only two sites (Sandstone Point and Toulkerrie) appear to support the model, demonstrating significant deposition of fish remains over the last thousand years. Of the sites investigated since Walters' original study, only the Booral Shell Mound could be said to have evidence for significant fish discard, but even here the trend is towards decreasing discard through time (Figure 2 ). The significance of fish remains recovered from the Lazaret Midden and Waddy Point 1 Rockshelter sites is difficult to evaluate. Many of those contributing to the high NISP reported at the Lazaret Midden are actually highly fragmented fish spines from the $1 \mathrm{~mm}$ sieve and may not represent many individual fish, while at Waddy Point 1 Rockshelter actual fish bone data are not available and basal deposits were not reached. Although fish bone is present at other sites, at four of them its cultural status has been called into question (Cameron Point Site 62, King's Bore Sandblow 97, New Brisbane Airport, Tin Can Bay Site 75B), at two sites fish production may be associated with mortuary practices rather than subsistence (Broadbeach Burial Ground, Double Island Point), and at the remaining sites the evidence for fishing is confined to a few elements, potentially representing a single individual fish. At many sites no data are presented for the vertical distribution of fish remains in the deposit (Broadbeach Burial Ground, Lazaret Midden, New Brisbane Airport, NRS 8, Saint-Smith Midden), making assessments of change in discard patterns through time difficult. In sum, this overview indicates that it is difficult to characterise the distribution of fish remains in archaeological sites in southeast Queensland as a single consistent pattern.

\section{Discussion}

This review reveals three major impediments to accepting the Walters model of late Holocene fishery development. 
Table 3. Summary of southeast Queensland regional fish bone data.

\begin{tabular}{|c|c|c|c|c|c|}
\hline Site & $\begin{array}{l}\text { Date First } \\
\text { Fishing } \\
(\text { cal BP })^{1}\end{array}$ & NISP & MNI & $\begin{array}{l}\text { Weight } \\
\text { (g) }\end{array}$ & Comments \\
\hline Booral Shell Mound & $>3076$ & 1470 & 36 & - & $\begin{array}{l}\text { major fish discard; fish discard } \\
\text { before } 3000 \mathrm{BP} \text {; decreasing discard }\end{array}$ \\
\hline Bribie Island 9 & $<173$ & - & - & - & minimal \\
\hline Broadbeach Burial Ground & $<1290$ & 34 & - & - & $\begin{array}{l}\text { production possibly associated with } \\
\text { non-subsistence activities; no data } \\
\text { for vertical distribution; minimal }\end{array}$ \\
\hline Cameron Point Site 62 & $<147$ & - & 1 & 0.15 & $\begin{array}{l}\text { possible non-cultural origin; } \\
\text { minimal }\end{array}$ \\
\hline Double Island Point & $<219$ & - & 1 & 0.31 & $\begin{array}{l}\text { production possibly associated with } \\
\text { non-subsistence activities; minimal }\end{array}$ \\
\hline First Ridge 19B & $<673$ & 1 & 1 & - & minimal \\
\hline King's Bore Sandblow & modern & - & - & $<2.59$ & $\begin{array}{l}\text { probable non-cultural origin; } \\
\text { minimal }\end{array}$ \\
\hline Lazaret Midden & $<1222$ & 60000 & - & 250 & $\begin{array}{l}\text { highly fragmented; no data for } \\
\text { vertical distribution }\end{array}$ \\
\hline Little Sandhills & modern & 18 & - & - & modern; minimal \\
\hline Minner Dint & $<523$ & 190 & 10 & 23.55 & $22 \mathrm{~g}$ in one $5 \mathrm{~cm}$-deep unit \\
\hline New Brisbane Airport & $>5586$ & few elements & - & - & $\begin{array}{l}\text { fish bone present by } 5000 \mathrm{BP} \text {; } \\
\text { possible non-cultural origin; no data } \\
\text { for vertical distribution; minimal }\end{array}$ \\
\hline NRS 7 & modern & 126 & - & - & modern; minimal \\
\hline NRS 8 & $<55$ & 61 & - & - & $\begin{array}{l}\text { modern; no data for vertical } \\
\text { distribution; minimal }\end{array}$ \\
\hline NRS 10 & modern & 87 & - & - & modern; minimal \\
\hline Saint-Smith Midden & $>816$ & - & - & 40.5 & $\begin{array}{l}\text { major fish discard; confined last } \\
1000 \text { years; no data for vertical } \\
\text { distribution }\end{array}$ \\
\hline Sandstone Point & $<2328$ & 37754 & - & - & major fish discard \\
\hline St Helena Island & $>1826$ & 576 & - & - & decreasing discard \\
\hline Teewah Beach Site 26 & $<861$ & - & 1 & 1.73 & minimal \\
\hline Tin Can Bay Site 75B & $<309$ & - & 1 & 0.01 & $\begin{array}{l}\text { possible non-cultural origin; } \\
\text { minimal }\end{array}$ \\
\hline Toulkerrie & $<2328$ & 40773 & - & - & major fish discard \\
\hline Waddy Point 1 Rockshelter & $<930$ & - & - & - & actual fish remains not quantified \\
\hline Wallen Wallen Creek & $<3000$ & 296 & - & - & $\begin{array}{l}\text { analysed assemblage not dated; } \\
\text { decreasing discard }\end{array}$ \\
\hline White Patch Site 3 & $<649$ & - & - & - & minimal \\
\hline
\end{tabular}


First, some of its basic predictions are simply not supported by the quantitative data. Numerous sites in the region dating to the late Holocene contain no evidence at all for fishing (Figure 13). Of the five sites which exhibit major fish discard, three (the Booral Shell Mound, Wallen Wallen Creek and St Helena Island) actually demonstrate decreasing rather than increasing rates of fish bone discard through time (Table 3). Second, the small samples employed by Walters raise critical problems for the examination of regional production strategies over time. Small sample sizes combined with the effect of variable recovery procedures considerably reduces confidence in the cited data and thus the reliability of the model (see below). Third, because half of the faunal assemblages analysed in Walters' original study are undated, any estimate of discard rates through time is problematic. Only two sites (Toulkerrie and Sandstone Point), therefore, appear to support the model, demonstrating trends towards significant deposition of fish remains over the last 1,000 years, but even at those sites major problems remain to be addressed.

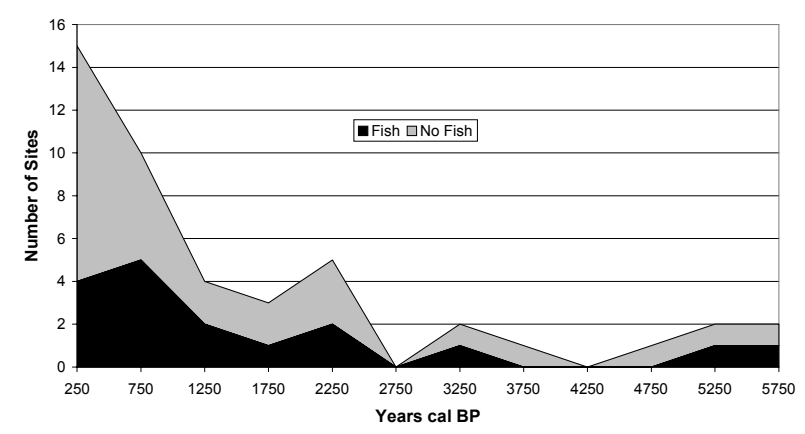

Figure 13. Number of new sites established through time using earliest dates showing sites with fish bone versus sites without fish bone.

At Toulkerrie, the sample excavated and analysed by Walters was not dated. Walters' assumption of contemporaneity with nearby occupation dated by Hall (1984) to about $400 \mathrm{BP}$ needs to be treated with caution as later research conducted by Hall and Bowen (1989) revealed significant differences in the timing of initial occupation across the site. Recent excavations at the site have revealed an occupational sequence spanning the last 2,300 years, indicating that people occupied this locality for some time (see Bowen 1989; Hall and Bowen 1989).

The Sandstone Point site is clearly not typical of coastal archaeological deposits in southeast Queensland. Three main factors set the foredune deposits at Sandstone Point apart. First, the cultural deposits on the foredune accumulated over a relatively short period of time. Second, there appear to be relatively low rates of mechanical damage to bone elements compared to other sites in the region (Walters 1986:248). Third, the abundance of fish scales recovered from the excavation suggest favourable preservation conditions (Walters 1986:235). Historical literature characterises the Toorbul Point area (where Sandstone Point is situated) as an important Aboriginal inter-group gathering site, at least in the contact period (Nolan 1986). Thus, major marine fishery production at this site, at least in the more recent past, may have taken place within a very specific inter-group production context. However, ongoing analysis of the Sandstone Point material by Walters (see Hiscock and Walters 1994) may clarify the apparently anomalous status of the site.

Although the actual archaeological evidence for marine fishery intensification (i.e. fish bones) is meagre, a number of factors may have influenced the representation of fish remains in the southeast Queensland archaeological record. These include differential site preservation, site-specific taphonomic factors, excavation strategies, recovery techniques and quantitative methods. Each of these factors is briefly discussed below.

\section{Geomorphology}

Geomorphic processes (especially the impact of sea level change and erosion on the representation of archaeological material) have featured prominently in discussions of the southeast Queensland coastal archaeological record (e.g. David and Chant 1995; Hall and Lilley 1987). The problem is particularly acute in this region because the absence of major rock formations close to the coast and the dominance of sandy sediments have resulted in complex patterns of coastal sedimentation and landscape development operating over both short and long time spans (e.g. Cotter 1996). As David and Chant (1995:429) note, in southeast Queensland 'the influence of changing sea levels on site survival has to be considered before occupational trends can be inferred from the archaeological record'.

Sea level fluctuations, coastal erosion, cyclonic and storm-surge activity and coastal progradation have resulted in differential destruction of the coastal archaeological record (e.g. Bird 1992; Head 1987; Rowland 1989). In the study region, approximately $20,000 \mathrm{~km}^{2}$ of land has been submerged by transgressing seas over the last 18,000 years. This fact has obvious implications for the representation of coastal archaeological sites pre-dating the close of the transgression (c.6,000 BP). Thus, the archaeological record is expected to be truncated and biased towards later Holocene adaptations. The simplest explanation for the near-absence of fish remains and sites before 3,000 BP is that known coastal sites were formed in landscapes which only date to the late Holocene. Detailed geomorphological studies from the entire region are now required to establish a framework for evaluating the structure of this archaeological evidence. In sum, as all the assemblages used by Walters were derived from geomorphological contexts of late Holocene age, it is perhaps not surprising that their components only date to the late Holocene.

\section{Taphonomic Factors}

A further complication is the potential role of taphonomic factors in structuring archaeological assemblages in the region. Walters (1986:256) has repeatedly argued that the 'methodological controls' employed in his investigations 'imply that the patterns of distribution and abundance ... adequately reflected composition of the prehistoric catches'. The only archaeological marine fish bone samples currently available, however, are from shell midden contexts. This is unlikely to represent the range of fish production and consumption activities recorded in the ethnohistoric literature. For example, several accounts note the immediate consumption of fish at the site of capture on the beach probably below tidal range (McNiven 1992b). 
Like all faunal remains, fish bone is susceptible to a wide variety of possible post-depositional modification (see Lyman 1994a). Colley (1990:215), for example, noted that fish are "particularly vulnerable to the effects of differential preservation because some fish bones are extremely fragile while others are robust'. Despite publishing a paper on the role of dogs in the representation of faunal remains in the archaeological record (Walters 1984), Walters does not consider the potential role of domestic dogs in modifying fish bone accumulations in his southeast Queensland study. His own and other ethnoarchaeological research has established that the remains of small-bodied animals such as fish are especially vulnerable to modification by dogs, with documented losses of up to $97 \%$ of skeletal elements (e.g. Hudson 1993; Jones 1986; Kent 1981, 1993; Lyon 1970; Walters 1984, 1985).

Early historic accounts document the presence of numerous dogs at Aboriginal camp sites; Flinders (1814) for example notes such on Coochie Mudlo Island. There is evidence for scavenging by dogs in the study region by c.4,000 BP (see Novello 1989:73) and recent studies of dingo scavenging behaviour in the area demonstrate that fish comprise a significant part of the diet (Twyford 1994, 1995). It may well be that the apparent abundance of fish remains in excavated island sites (Lazaret Midden, St Helena Island) is related to lower numbers of dogs relative to mainland areas. Thus, domestic dogs may have been a significant agent in structuring the representation of fish remains in archaeological assemblages.

Other taphonomic factors influencing the survival of fish bone include burning and post-depositional diagenesis. In fact, the two may be related in that the high proportions of burnt bone recovered in the region (Walters 1986:240) could indicate the loss of unburnt bone. It is unlikely that chemical attrition alone could account for the distribution of fish remains since the majority of excavated sites are fairly alkaline ( $\mathrm{pH}=7.0$ to 8.0). Two sites, Cameron Point Site 62 and Tin Can Bay Site 75B, have recorded pH levels as low as 4.0 and 4.5 respectively, which would not be conducive to survival of fish bone, although at both these sites other faunal remains (such as shellfish) did not appear to be adversely affected by these conditions (see McNiven 1990a). Further studies are required to define the various taphonomic processes affecting fish representation in the archaeological record of the region as a basis for undertaking valid inter-site comparisons of faunal assemblages (Amorosi et al. 1996).

\section{Excavation Strategies}

Any estimation of the value of the Walters model as an heuristic device must be tempered by recognition of his extremely small sample size. Walters provides no rationale or discussion of sampling adequacy other than a rather vague statement that all shore types were represented (Walters 1986:209). In the 1986 study, he conducted independent excavations at only two sites, Sandstone Point and Toulkerrie whereas all other supporting evidence is derived from excavations conducted by other investigators. In the main, the research designs used by these other researchers were directed at resolving issues of chronology and gross assemblage composition and not at characterising broad changes in fish production strategies. Of the eight sites employed in his original study (Walters 1986), five (St Helena Island, Wallen Wallen Creek, NRS 7, NRS 10 and Minner Dint) fall into this category.

A simple comparison of the area excavated and the total site area (see Table 1) demonstrates that the excavated fraction of archaeological deposits is much less than $0.5 \%$ for most of the sites reviewed, with the Broadbeach Burial Ground providing the exception. The high degree of spatial heterogeneity evident at the two middens which have been subjected to larger-scale excavation, Sandstone Point (Figure 6) and Toulkerrie (Figure 10), should serve as a caution against accepting results from small samples as representative of entire sites (see O’Neil 1993).

Given the small sample of excavated sites and of recovered fish remains from them, the total range of prehistoric fishing activities in southeast Queensland is unlikely to be adequately represented. Contrary to Walters' assertion, his sample cannot be expected to encompass the full range of intra-site variability, let alone provide sufficient data to enable meaningful inter-site comparisons and insights into regional processes (see Anderson 1973; Plog and Hegman 1993). To date, the types of sampling procedures employed in the excavation of shell midden deposits in southeast Queensland have been unsuited to characterising the internal diversity and composition of sites at any but the coarsest level.

\section{Recovery Techniques}

Another important sampling consideration is the efficacy of recovery techniques to yield data to evaluate fishing. Various screening experiments have demonstrated that mesh sizes create significant biases in faunal recovery (e.g. O’Neil 1993; Shaffer 1992; Shaffer and Sanchez 1994). Experiments which have included fish bones indicate that mesh sizes between $0.5 \mathrm{~mm}$ and $2 \mathrm{~mm}$ are required for maximum representative recovery (Casteel 1970, 1972, 1976a; Colley 1990; Gordon 1993). Indeed, Casteel (1976a, 1976b) has argued that column- or core-sampling is the only reliable method for representative recovery of fish remains. With the exception of the Lazaret Midden, where $1 \mathrm{~mm}$ screens were used, and the two Booral sites and St Helena Island where $2 \mathrm{~mm}$ screens were employed, $3 \mathrm{~mm}$ mesh is almost universally the smallest screen size used in excavations in the area (Table 1). This factor may have had a significant impact on the fish representation in samples.

In an earlier study, Walters (1979) found that as much as $80 \%$ of fish remains passed through $3 \mathrm{~mm}$ mesh (based on analysis of a single $661.6 \mathrm{~g}$ bulk sample from Toulkerrie). Given this result it is somewhat surprising that he placed so much credence in the fish bone assemblages used for his later study which were derived almost exclusively from $3 \mathrm{~mm}$ sieve residues. Walters' study also demonstrated that the use of larger mesh sizes biased recovery against some fish taxa with small diagnostic skeletal elements, such as mullet and whiting (see also Hall 1980:105-106). Also, the use of different sieve sizes makes it difficult to compare the representation of fish remains between sites. For example, both Frankland (1990) and Ross (2001) have attempted to directly compare the abundance of fish remains recovered with $2 \mathrm{~mm}$ and $1 \mathrm{~mm}$ screens respectively, with those derived from sites around Moreton Bay where $3 \mathrm{~mm}$ screens were used. 


\section{Analytical Methods}

A variety of abundance measures has been employed in the analysis of fish remains from archaeological sites in the region. For example, Walters (1986) used number of identified specimens (NISP), McNiven (1990a) used both weight and minimum number of individuals (MNI) and Frankland (1990) used MNI and NISP. These abundance measures are not necessarily comparable (e.g. Grayson 1979, 1984). Figure 14 reveals major discrepancies between patterns revealed by NISP and those given by MNI in the abundance of fish remains from the Booral Shell Mound.

NISP is particularly prone to problems of inter-site comparability, given the potential effects of taphonomic factors and differences in the way that different investigators calculate the measure. Lyman (1994b:38) defines NISP as 'the number of identified specimens per taxon ... The taxon can be a subspecies, genus, family, or higher taxonomic category'. Although there is some disagreement over whether the term 'specimen' can be equated with 'element' or 'fragment', there appears to be consensus on the meaning of 'taxon'. All investigators who have used NISP as a measure of fish abundance in southeast Queensland have adopted the highest taxonomic category possible - Pisces.

The use of NISP also raises significant problems in Walters' application of the measure to calculate the abundance of fish remains discarded in various time intervals. The sites in his sample are not necessarily comparable even at a basic level. Direct inter-site comparison of these data is based on an assumption that all fish remains were subject to identical preparation, discard and post-depositional alteration and that the remains of all fish taxa respond to these factors in the same way (see Brian 1994). Walters (1986:248; cf. 1992c:35) has already demonstrated that even in his small sample there were significant differences between fish bone assemblages in patterns of mechanical damage.

Another problem in Walters' analysis is the equation of excavation units with temporal units in presenting discard patterns at particular sites. In this form of analysis there is an explicit assumption that each excavation unit represents an equivalent (and therefore comparable) period of time (Frankel 1988) and a constant rate of accumulation of both cultural materials and natural sediments. As Bird and Frankel (1991:181) note, these arbitrary analytical units 'combine material from an unknown number of activities or episodes of occupation into longer-term archaeological units'. Although excavation units are useful as a descriptive framework for defining assemblage composition and variability, they are inappropriate for addressing questions of change through time.

These chronological limitations are exacerbated when inter-site comparisons are attempted. At the Booral Shell Mound site, for example, a series of five radiocarbon dates from a single $50 \mathrm{~cm} \times 50 \mathrm{~cm}$ pit provided Frankland (1990) with a well-dated sequence from which to calculate rates of discard of cultural material in 100-year intervals. This analysis demonstrated that in terms of NISP, the most intensive period of fish discard at the site occurred between 2,950 and 2,790 BP (see Figure 2). This form of analysis is not possible for most other coastal sites because of poor chronological resolution.

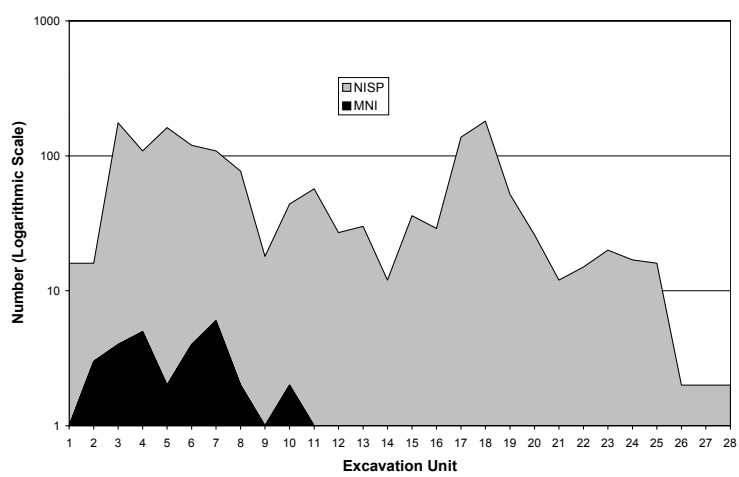

Figure 14. Abundance of fish remains calculated using both NISP and MNI methods, Booral Shell Mound, Square A (after Frankland 1990:59, 60). A logarithmic scale is employed so that small MNI figures are visible.

\section{Conclusion}

All I have tried to show, here and elsewhere since the late $1980 \mathrm{~s}$, is that on the evidence we have, the interpretation I have given is the most parsimonious one that adheres to the data (Walters 1992c:37, original emphasis).

The review of the evidence for marine fishing in southeast Queensland demonstrates that the spatial and temporal distribution of fish remains in coastal sites is highly variable and is not simply characterised by increasing discard of fish remains through time. In fact, most coastal sites dating to the late Holocene do not contain fish remains at all, while at others fish abundance actually decreases through time. However, it is difficult to confidently define regional patterns in the fish evidence at this stage as a combination of factors, such as discard behaviour, taphonomic factors, recovery procedures and quantification techniques, may have a significant impact on the comparability of assemblages and the validity of intersite comparisons. In sum, I do not deny that (a) marine fish may have been a significant component of Aboriginal subsistence in the past, nor that (b) an intensification of marine fishing occurred in Moreton Bay in the late Holocene. I simply point out that there is no current archaeological evidence available to support a claim for intensifying marine fishing in southeast Queensland.

\footnotetext{
Notes

${ }^{1}$ Radiocarbon ages in this paper are reported as conventional radiocarbon ages (Stuiver and Polach 1977). That is, they are corrected for isotopic fractionation and not corrected for marine reservoir effect or any other correction. Where not otherwise stated, the sample material used to determine each date is supplied with the laboratory number in the text. Where calibrated ages are reported, conventional radiocarbon ages were calibrated using the CALIB (v4.3) computer program (Stuiver and Reimer 1993) using the datasets of Stuiver et al. (1998) with no laboratory error multiplier. For shell dates, the central Queensland $\Delta$ R of $10 \pm 7$ recommended by Ulm (2002a, 2002b) is adopted. For charcoal dates, 24 years were subtracted before calibration to correct for ${ }^{14} \mathrm{C}$ variation between northern and southern hemispheres (after Stuiver and Reimer 1993). Calibrated ages for other conventional radiocarbon ages may be found in Ulm and Reid (2000). For a discussion of regional marine reservoir issues see Ulm (2002a, 2002b).
} 


\section{Acknowledgements}

Much of the research presented in this paper was undertaken as part of BA (Hons) studies in the (then) Department of Anthropology and Sociology, University of Queensland (see Ulm 1995). I am indebted to Jay Hall and Annie Ross (School of Social Science, University of Queensland) and Ian Lilley (Aboriginal and Torres Strait Islander Studies Unit, University of Queensland), for constructive advice, support and encouragement. For valuable advice, comments and suggestions which contributed to the improvement of this paper I wish to thank Bryce Barker, Deborah Brian, Daniel Cummins, Bruno David, Peter Dwyer, Luke Godwin, Harry Lourandos, Paul McInnes, Rob Neal, Ian McNiven, Monica Minnegal, Judith Powell, Jonathan Prangnell, Jill Reid, John Richter, Richard Robins, Mike Rowland, Leonn Satterthwait and Deborah Vale.

\section{References}

Aiken, G., A. Nicholson and S. Cane 1992 North Coast Middens: A Report on the Distribution, Type and Representation of Middens in Northern New South Wales and South East Queensland. Unpublished report to the Australian Heritage Commission, Canberra.

Alfredson, G. 1983 St. Helena Island: A changing pattern of exploitation? Australian Archaeology 17:79-86.

Alfredson, G. 1984a An Archaeological Investigation into the Aboriginal use of St. Helena Island, Moreton Bay. Unpublished B.A. (Hons) thesis, Department of Anthropology and Sociology, University of Queensland, Brisbane.

Alfredson, G. 1984b The Aboriginal use of St. Helena Island The archaeological evidence. In R.J. Coleman, J. Covacevich and P. Davie (eds), Focus on Stradbroke: New Information on North Stradbroke Island and Surrounding Areas, 19741984, pp.1-8. Brisbane: Boolarong Publications.

Amorosi, T., J. Woollett, S. Perdikaris and T. McGovern 1996 Regional zooarchaeology and global change: Problems and potentials. World Archaeology 28(1):126-157.

Anderson, A.J. 1973 A critical evaluation of the methodology of midden sampling. New Zealand Archaeological Association Newsletter 16:119-127.

Arnold, J. 1993 Labor and the rise of complex hunter-gatherers. Journal of Anthropological Archaeology 12(3):75-119.

Bartholomai, A. 1976 Faunal remains excavated from site Q1, Broadbeach, southeast Queensland. Appendix B. In L. Haglund, The Broadbeach Aboriginal Burial Ground: An Archaeological Analysis, pp.90-93. St Lucia: University of Queensland Press.

Bird, C.F.M. and D. Frankel 1991 Problems in constructing a prehistoric regional sequence: Holocene southeast Australia. World Archaeology 23(2):179-192.

Bird, M.K. 1992 The impact of tropical cyclones on the archaeological record: An Australian example. Archaeology in Oceania 27(2):75-86.

Bowen, G. 1989 A Model for Moreton Island Prehistory: Colonisation, Settlement and Subsistence. Unpublished B.A. (Hons) thesis, Department of Anthropology and Sociology, University of Queensland, Brisbane.

Bowen, G. 1998 Towards a generic technique for dating stone fish traps and weirs. Australian Archaeology 47:39-43.

Brian, D. 1994 Shall I Compare Thee to a Fish?: A Comparative Taphonomic Analysis of Vertebrate Remains from Nara Inlet Art Site, Hook Island, Central Queensland Coast. Unpublished B.A. (Hons) thesis, Department of Anthropology and Sociology, University of Queensland, Brisbane.
Casteel, R.W. 1970 Core and column sampling. American Antiquity 35(4):465-467.

Casteel, R.W. 1972 Some biases in the recovery of archaeological faunal remains. Proceedings of the Prehistoric Society 38:382-388.

Casteel, R.W. 1976a Comparison of column and whole unit samples for recovering fish remains. World Archaeology 8(2):192-198.

Casteel, R.W. 1976b Fish Remains in Archaeology and PalaeoEnvironmental Studies. London: Academic Press.

Colley, S.M. 1990 The analysis and interpretation of archaeological fish remains. Archaeological Method and Theory 2:207-253.

Cotter, M. 1996 Holocene environmental change in Deception Bay, southeast Queensland: A palaeogeographical contribution to MRAP stage II. In S. Ulm, I. Lilley and A. Ross (eds), Australian Archaeology '95: Proceedings of the 1995 Australian Archaeological Association Annual Conference, pp.193-205. Tempus 6. St Lucia: Anthropology Museum, Department of Anthropology and Sociology, University of Queensland.

Crooks, J. 1982 Report of Three Excavations at Pumicestone Passage, Moreton Bay, Southeast Queensland. Unpublished B.A. (Hons) thesis, Department of Anthropology and Sociology, University of Queensland, Brisbane.

David, B. and D. Chant 1995 Rock art and regionalisation in north Queensland prehistory. Memoirs of the Queensland Museum 37(2):357-528.

Flinders, M. 1814 A Voyage to Terra Australis. 2 vols and atlas. London: G. and W. Nicol.

Frankel, D. 1988 Characterising change in prehistoric sequences: A view from Australia. Archaeology in Oceania 23(2):41-48.

Frankland, K. 1990 Booral: A Preliminary Investigation of an Archaeological Site in the Great Sandy Strait Region, Southeast Queensland. Unpublished B.A. (Hons) thesis, Department of Anthropology and Sociology, University of Queensland, Brisbane.

Gordon, E.A. 1993 Screen size and differential faunal recovery: A Hawaiian example. Journal of Field Archaeology 20(4):453-460.

Gowlett, J.A.J., R.E.M. Hedges, I.A. Law and C. Perry 1987 Radiocarbon dates from the Oxford AMS system: Archaeometry datelist 5. Archaeometry 29(1):125-155.

Grayson, D.K. 1979 On the quantification of vertebrate archaeofaunas. Advances in Archaeological Method and Theory 2:199-238.

Grayson, D.K. 1984 Quantitative Zooarchaeology: Topics in the Analysis of Archaeological Faunas. Orlando: Academic Press.

Haglund, L. 1974 The Sandstone Point shell midden: A preliminary report. Appendix 5. In J. Stockton, Report of an Archaeological Survey in the Vicinity of Bribie Island, South-East Queensland, pp.118-131. Unpublished B.A. (Hons) thesis, Department of Anthropology and Sociology, University of Queensland, Brisbane.

Haglund, L. 1976 The Broadbeach Aboriginal Burial Ground: An Archaeological Analysis. St Lucia: University of Queensland Press.

Hall, J. 1980 Minner Dint: A recent Aboriginal midden on Moreton Island, southeastern Queensland. In P.K. Lauer (ed.), Occasional Papers in Anthropology 10:94-112. St Lucia: Anthropology Museum, University of Queensland. 
Hall, J. 1982 Sitting on the crop of the bay: An historical and archaeological sketch of Aboriginal settlement and subsistence in Moreton Bay, southeast Queensland. In S. Bowdler (ed.), Coastal Archaeology in Eastern Australia: Proceedings of the 1980 Valla Conference on Australian Prehistory, pp.79-95. Occasional Papers in Prehistory 11. Canberra: Department of Prehistory, Research School of Pacific Studies, Australian National University.

Hall, J. 1984 Exploratory excavation at Toulkerrie midden (LB:B75), Moreton Island, S.E. Queensland. Queensland Archaeological Research 1:61-84.

Hall, J. 1987 A short prehistory of the Moreton Region. In R. Fisher (ed.), Brisbane: Aboriginal, Alien, Ethnic, pp.14-22. Brisbane History Group Papers 5. St Lucia: Department of History, University of Queensland.

Hall, J. 199020000 years of human impact on the Brisbane River and environs. In P. Davie, E. Stock and D.L. Choy (eds), The Brisbane River: A Source-Book for the Future, pp.175-182. Brisbane: Australian Littoral Society and the Queensland Museum.

Hall, J. 1991 The Bribie Island Forest Archaeological Project: Phase 1 - Assessment of Archaeological Values Prior to Logging. UQASU Report 195. Brisbane: University of Queensland Archaeological Services Unit.

Hall, J. 1995 The Saint-Smith Midden Site at Beachmere, S.E. Queensland: A Report on Archaeological Fieldwork 1994. Unpublished report to the Cultural Heritage Section, Queensland Department of Environment and Heritage, Brisbane.

Hall, J. 1999 The impact of sea level rise on the archaeological record of the Moreton region, southeast Queensland. In J. Hall and I. McNiven (eds), Australian Coastal Archaeology, pp.169-184. Research Papers in Archaeology and Natural History 31. Canberra: ANH Publications, Department of Archaeology and Natural History, Research School of Pacific and Asian Studies, Australian National University.

Hall, J. 2000 Fishing for fish - No wallabies: An unusual marine intensification strategy for the late Holocene settlement of Moreton Island, southeast Queensland. In A. Anderson and T. Murray (eds), Australian Archaeologist: Collected Papers in Honour of Jim Allen, pp.201-216. Canberra: Coombs Academic Publishing, Australian National University.

Hall, J. and G. Bowen 1989 An excavation of a midden complex at the Toulkerrie Oysterman's lease, Moreton Island, SE Queensland. Queensland Archaeological Research 6:3-27.

Hall, J. and P. Hiscock 1988 The Moreton Regional Archaeological Project (MRAP) - Stage II: An outline of objectives and methods. Queensland Archaeological Research 5:4-24.

Hall, J. and I. Lilley 1987 Excavation at the New Brisbane Airport site (LB:C69): Evidence for early mid-Holocene coastal occupation in Moreton Bay, SE Queensland. Queensland Archaeological Research 4:54-79.

Head, L. 1987 The Holocene prehistory of a coastal wetland system: Discovery Bay, southeastern Australia. Human Ecology 15(4):435-462.

Hiscock, P. and I. Walters 1994 Archaeology at the Northern Territory University: Update May 1993. Australian Archaeology 38:51-55.

Hudson, J. 1993 The impacts of domestic dogs on bone in forager camps; or, the dog-gone bones. In J. Hudson (ed.), From Bones to Behavior, pp.301-323. Carbondale: Southern Illinois University.

Jones, A.K.G. 1986 Fish bone survival in the digestive systems of the pig, dog and man: Some experiments. In D.C.
Brinkhuizen and A.T. Clason (eds), Fish and Archaeology: Studies in Osteometry, Taphonomy, Seasonality and Fishing Methods, pp.53-61. BAR International Series 294. Oxford: British Archaeological Reports.

Kent, S. 1981 The dog - Archaeologist's best friend or worst enemy: The spatial distribution of faunal remains. Journal of Field Archaeology 8(3):367-372.

Kent, S. 1993 Variability in faunal assemblages: The influence of hunting skill, sharing, dogs, and mode of cooking on faunal remains at a sedentary Kalahari community. Journal of Anthropological Archaeology 12(3):323-385.

Lyman, R.L. 1994a Vertebrate Taphonomy. Cambridge: Cambridge University Press.

Lyman, R.L. 1994b Quantitative units and terminology in zooarchaeology. American Antiquity 59(1):36-71.

Lyon, P. 1970 Differential bone destruction: An ethnographic example. American Antiquity 35(2):213-215.

McNiven, I.J. 1985 An archaeological survey of the Cooloola region, S.E. Queensland. Queensland Archaeological Research 2:4-37.

McNiven, I.J. 1990a Prehistoric Aboriginal Settlement and Subsistence in the Cooloola Region, Coastal Southeast Queensland. Unpublished $\mathrm{PhD}$ thesis, Department of Anthropology and Sociology, University of Queensland, Brisbane.

McNiven, I.J. 1990b Blowout taphonomy: Non-cultural associations between faunal and stone artefact assemblages along the Cooloola coast, southeast Queensland. Australian Archaeology 31:67-74.

McNiven, I.J. 1991a Teewah Beach: New evidence for Holocene coastal occupation in coastal southeast Queensland. Australian Archaeology 33:14-27.

McNiven, I.J. 1991b Settlement and subsistence activities along Tin Can Bay, southeast Queensland. Queensland Archaeological Research 8:85-107.

McNiven, I.J. 1991c The Double Island Point Aboriginal burials, coastal southeast Queensland. Australian Archaeology 32:1016.

McNiven, I.J. 1992a Sandblow sites in the Great Sandy Region, coastal southeast Queensland: Implications for models of late Holocene rainforest exploitation and settlement restructuring. Queensland Archaeological Research 9:1-16.

McNiven, I.J. 1992b Ethnohistorical reconstructions of Aboriginal lifeways along the Cooloola coast, southeast Queensland. Proceedings of the Royal Society of Queensland 102:5-24

McNiven, I.J. 1999 Fissioning and regionalisation: The social dimensions of changes in Aboriginal use of the Great Sandy Region, southeast Queensland. In J. Hall and I. McNiven (eds), Australian Coastal Archaeology, pp.157-168. Research Papers in Archaeology and Natural History 31. Canberra: ANH Publications, Department of Archaeology and Natural History, Research School of Pacific and Asian Studies, Australian National University.

McNiven, I.J., I. Thomas and U. Zoppi 2002 Fraser Island Archaeological Project (FIAP): Background, aims and preliminary results of excavations at Waddy Point 1 Rockshelter. Queensland Archaeological Research 13:1-20.

Morwood, M.J. 1986 The archaeology of art: Excavations at Gatton and Maidenwell Rockshelters, S.E. Queensland. Queensland Archaeological Research 3:88-132.

Morwood, M.J. 1987 The archaeology of social complexity in south-east Queensland. Proceedings of the Prehistoric Society 53:337-350. 
Murphy, A.M.C. 1991 Into a Kingdom of Bones: A Metrical Analysis of the Pectoral Girdles and Innominates of the Broadbeach Australian Aborigines and the New Zealand Polynesians. Unpublished PhD thesis, Department of Anatomy, University of Queensland, Brisbane.

Neal, R. 1984 Rescue Archaeology Near Blue Lake, North Stradbroke Island. Unpublished report to Associated Minerals Consolidated Ltd and the Archaeology Branch, Department of Community Services, Brisbane.

Neal, R. and E. Stock 1986 Pleistocene occupation in the southeast Queensland coastal region. Nature 323:618-621.

Nolan, A. 1986 Sandstone Point: Temporal and Spatial Patterns of Aboriginal Site Use at a Midden Complex, South-East Queensland. Unpublished B.A. (Hons) thesis, Department of Anthropology and Sociology, University of Queensland, Brisbane.

Novello, M. 1989 A Taphonomic Analysis of the Faunal Remains from Platypus Rockshelter (Site KB:A70), S.E. Queensland. Unpublished B.A. (Hons) thesis, Department of Anthropology and Sociology, University of Queensland, Brisbane.

O’Neil, D.H. 1993 Excavation sample size: A cautionary tale. American Antiquity 58(3):523-529.

Plog, S. and M. Hegmon 1993 The sample size-richness relation: The relevance of research questions, sampling strategies, and behavioral variation. American Antiquity 58(3):489-496.

Richardson, N. 1984 An archaeological investigation of sandmining lease SML 931 on North Stradbroke Island. In R.J. Coleman, J. Covacevich and P. Davie (eds), Focus on Stradbroke: New Information on North Stradbroke Island and Surrounding Areas, 1974-1984, pp.23-32. Brisbane: Boolarong Publications.

Robins, R.P. 1983 This Widow Land: An Evaluation of Public Archaeology in Queensland using Moreton Island as a Case Study. Unpublished M.A. thesis, Department of Anthropology and Sociology, University of Queensland, Brisbane.

Robins, R.P. 1984 The excavation of three archaeological sites on Moreton Island: First Ridge and the Little Sandhills. Queensland Archaeological Research 1:51-60.

Ross, A. 2001 The Aboriginal Moreton Bay fishery: Using archaeological evidence to reply to Walters. Australian Aboriginal Studies 2001(2):63-65.

Ross, A. and S. Coghill 2000 Conducting a community-based archaeological project: An archaeologist's and a Koenpul man's perspective. Australian Aboriginal Studies 2000(1\&2):76-83.

Ross, A. and R. Duffy 2000 Fine mesh screening of midden material and the recovery of fish bone: The development of flotation and deflocculation techniques for an efficient and effective procedure. Geoarchaeology: An International Journal 15(1):21-41.

Rowland, M.J. 1989 Population increase, intensification or a result of preservation?: Explaining site distribution patterns on the coast of Queensland. Australian Aboriginal Studies 2:32-41.

Shaffer, B.S. 1992 Quarter-inch screening: Understanding biases in recovery of vertebrate faunal remains. American Antiquity 57(2):129-136.

Shaffer, B.S. and J.L.J. Sanchez 1994 Comparison of 1/8"- and 1/4"- mesh recovery of controlled samples of small-tomedium-sized mammals. American Antiquity 59(3):525-530.

Smith, A.D. 1992 An Archaeological Site Location and Subsistence-Settlement Analysis of Bribie Island, Southeast
Queensland. Unpublished B.A. (Hons) thesis, Department of Anthropology and Sociology, University of Queensland, Brisbane.

Smith, J.R. and H.J. Hall 1996 Beaudesert Shire Regional Archaeological Project. Unpublished report to the Australian Heritage Commission, Canberra.

Stuiver, M. and H.A. Polach 1977 Discussion: Reporting of ${ }^{14} \mathrm{C}$ data. Radiocarbon 19(3):355-363.

Stuiver, M. and P.J. Reimer 1993 Extended ${ }^{14} \mathrm{C}$ data base and revised CALIB $3.0{ }^{14} \mathrm{C}$ age calibration program. Radiocarbon 35(1):215-230.

Stuiver, M., P.J. Reimer, E. Bard, J.W. Beck, G.S. Burr, K.A. Hughen, B. Kromer, G. McCormac, J. ver der Plicht and M. Spurk 1998 INTCAL98: Radiocarbon age calibration 24,000 - 0 cal BP. Radiocarbon 40(3):1041-1083.

Twyford, K. 1994 Investigations into the Diet of Dingoes on Fraser Island: Interim Report. Unpublished report to the Natural Resource Mangement (Great Sandy) Division, Central Coast Region, Queensland Department of Environment and Heritage.

Twyford, K. 1995 Investigations into the Dietary Ecology of Dingoes on Fraser Island: Third Interim Report. Unpublished report to the Natural Resource Mangement (Great Sandy) Division, Central Coast Region, Queensland Department of Environment and Heritage.

Ulm, S. 1995 Fishers, Gatherers and Hunters on the Moreton Fringe: Reconsidering the Prehistoric Aboriginal Marine Fishery in Southeast Queensland, Australia. Unpublished B.A. (Hons) thesis, Department of Anthropology and Sociology, University of Queensland, Brisbane.

Ulm, S. 2002a Marine and estuarine reservoir effects in central Queensland, Australia: Determination of $\Delta \mathrm{R}$ values. Geoarchaeology: An International Journal 17(4):319-348.

Ulm, S. 2002b Calibrating marine radiocarbon dates: A guide to Australian $\triangle \mathrm{R}$ values. AACAI Newsletter 89:10-14.

Ulm, S. and J. Hall 1996 Radiocarbon and cultural chronologies in southeast Queensland prehistory. In S. Ulm, I. Lilley and A. Ross (eds), Australian Archaeology '95: Proceedings of the 1995 Australian Archaeological Association Annual Conference, pp.45-62. Tempus 6. St Lucia: Anthropology Museum, Department of Anthropology and Sociology, University of Queensland.

Ulm, S. and J. Reid 2000 Index of dates from archaeological sites in Queensland. Queensland Archaeological Research 12:1129.

Walters, I.N. 1979 Information Loss in Zooarchaeology: A Study of Vertebrate Remains from Two Middens, Moreton Island, Queensland. Unpublished B.A. (Hons) thesis, Department of Anthropology and Sociology, University of Queensland, Brisbane.

Walters, I.N. 1984 Gone to the dogs: A study of bone attrition at a central Australian campsite. Mankind 14(5):398-400.

Walters, I.N. 1985 Bone loss: One explicit quantitative guess. Current Anthropology 26(5):642-643.

Walters, I.N. 1986 Another Kettle of Fish: The Prehistoric Moreton Bay Fishery. Unpublished PhD thesis, Department of Anthropology and Sociology, University of Queensland, Brisbane.

Walters, I.N. 1988 Fish hooks: Evidence for dual social systems in southeastern Australia? Australian Archaeology 27:98114.

Walters, I.N. 1989 Intensified fishery production at Moreton Bay, southeast Queensland, in the late Holocene. Antiquity 63:215224. 
Walters, I.N. 1992a Farmers and their fires, fishers and their fish: Production and productivity in pre-European south-east Queensland. Dialectical Anthropology 17:167-182.

Walters, I.N. 1992b Seasonality of fishing in south-east Queensland. Queensland Archaeological Research 9:29-34.

Walters, I.N. 1992c Antiquity of marine fishing in south-east Queensland. Queensland Archaeological Research 9:35-37.
Walters, I. 2001 The Aboriginal Moreton Bay fishery: Two things I still know - A response to Ross and Coghill. Australian Aboriginal Studies 2001(2):61-62. 